\title{
Productivity and Profits in the 1980s: Are They Really Improving?
}

OVER THE LAST TWO DECADES the U.S. economy has experienced a dramatic deterioration in both productivity and profit performance. After averaging more than 2.5 percent per year in the $1950 \mathrm{~s}$ and early 1960 s, labor productivity growth in the nonfarm sector slowed to about 2 percent per year between 1965 and 1973, and then plummeted to less than 1 percent per year between 1973 and 1980. At about the same time, the return on capital also sagged: after averaging 16 to 17 percent of output in the 1950s and early 1960s, net capital income (before-tax economic profits plus net interest paid) of nonfinancial corporations dropped to 13 to 14 percent of output by the mid-1970s.

Neither of these phenomena is well understood. The substandard performance of productivity in the 1970s has been variously attributed to higher energy prices, the "baby boom" population entering the labor force, inadequate incentives for innovation and capital formation, the general uncertainty that inflation brought to the economic environment, and a range of other possibilities. However, the case for any of these explanations of the productivity slowdown is empirically unproven and the slowdown remains a puzzle. ${ }^{1}$ Similarly, the "profit squeeze" of the

Comments by Steven Braun, James Glassman, David Stockton, and members of the Brookings Panel are gratefully acknowledged.

1. A discussion of various attempts to explain the productivity slowdown can be found in Edward F. Denison, Accounting for Slower Economic Growth: The United States in the 1970s (Brookings Institution, 1979), chapter 9. A wide range of hypotheses is also put forward in Federal Reserve Bank of Boston, The Decline in Productivity Growth, Conference Series 22 (FRBB, 1980). 
late 1960 s and early 1970 s has been widely analyzed. ${ }^{2}$ Some investigators emphasize the correlation between the rate of return to capital and productivity growth while others cite sticky real wages or deteriorating terms of trade; but a convincing explanation has yet to be made.

Despite this general lack of understanding, a feeling has arisen that both productivity growth and returns to capital should be substantially higher in the 1980s than they were in the 1970s. ${ }^{3}$ Part of this recent wave of optimism can be attributed to a reversal in most of the factors that are usually blamed for the slowdown: energy prices have stabilized; the baby boom population has been absorbed by the labor force; research and development spending is up; and the overall inflation rate is down.

In addition, it is widely believed that the hardships of the early eighties have paved the way for substantially improved economic performance for the rest of this decade and beyond. Much anecdotal evidence supports this view: after draconian cost-cutting measures, the U.S. automobile industry posted record profits last year; a huge amount of aging, unproductive steel capacity has been eliminated; work-rule changes and other efficiency improvements in a number of industries have been reported. On some interpretations, aggregate data also suggest some improvement in the underlying trend in labor productivity and the return to capital. In the last half of 1982 , productivity grew 1.8 percent per year, even though the recession had not yet ended; since the end of the recession, productivity has continued to improve and profits have skyrocketed, with nonfinancial corporations posting an 85 percent gain during 1983.

In this paper, the empirical evidence for and against a fundamental improvement in labor productivity growth and corporate profitability is

2. For the United States, see Martin Feldstein and others, "The Effective Tax Rate and the Pretax Rate of Return," Journal of Public Economics, vol. 21 (July 1983), pp. 12958. For cross-country comparisons of the profit squeeze, see Jeffrey D. Sachs, "Real Wages and Unemployment in the OECD Countries," BPEA, 1:1983, pp. 255-89, and Michael Bruno, "Raw Materials, Profits, and the Productivity Slowdown," Working Paper 660 (National Bureau of Economic Research, 1981).

3. For example, the cover story in the February 13, 1984, issue of Business Week was "The Revival of Productivity." It included projections by John Kendrick and Nestor Terleckyj that productivity growth in the 1980 s would average 2.5 to 3 percent, more than four times the 1973-79 rate. In "Will Productivity Growth Recover? Has It Done so Already?" American Economic Review, vol. 74 (May 1984, Papers and Proceedings, 1983), pp. 231-35, Martin Neil Baily's optimism is guarded, but he still concludes that productivity growth has improved substantially, at least in the manufacturing sector. 
considered in some detail, first by an examination of the raw data and then through a simple econometric model that exploits the interrelationship among productivity, price-cost margins, and income from capital. Because cyclical variability is important when the economy has been operating well below capacity, as in 1980-83, substantial emphasis is placed on consistent cyclical adjustment of the variables in the system.

\section{A Look at the Data}

The records of labor productivity and of capital's share of output over the last 30 years ${ }^{4}$ are illustrated in figure 1. The sharp rise in both series in 1983 might be interpreted as the start of a longer-term improvement in efficiency and profitability. However, productivity and the net capital share typically increase during a recovery, so the correct interpretation of the recent statistics requires a more careful analysis.

The parallel behavior of productivity and profits arises from the accounting identity relating factor payments to total output:

$$
\begin{aligned}
(\text { price level })(\text { real output })= & \text { (economic profits }+ \text { net interest payments }) \\
& + \text { (hourly wage costs) (labor hours }) \\
& + \text { (indirect business taxes) } \\
& + \text { (depreciation) }
\end{aligned}
$$

In the early stages of a recovery, real output rises faster than labor input, boosting labor productivity; since prices and wages tend to move more smoothly over time, the rise in productivity flows directly to the "bottom line," increasing profits. This process unwinds later in the business cycle, as labor input first catches up with output and then overshoots it late in the expansion.

Although much of the cyclical movement in income from capital can be traced to productivity developments, additional variation can arise

4. Throughout the paper, the sum of net interest and before-tax economic profits (book profits adjusted for inventory valuation and the difference between replacement-cost depreciation and depreciation allowable for tax purposes) divided by gross value added is used as the measure of income accruing to capital. Returns both to equity holders and to bond holders must be counted when calculating the income from capital. Also note that for a given debt/equity ratio, the distribution of this income between profits and interest changes dramatically with the inflation rate. The inflation premium in the nominal interest rate is a payment for a reduction in the real value of indebtedness and is therefore a part of the return to equity. 
Figure 1. Labor Productivity and Net Capital Share, 1954:1 to 1983:4a

In (output per hour), 1972 dollars

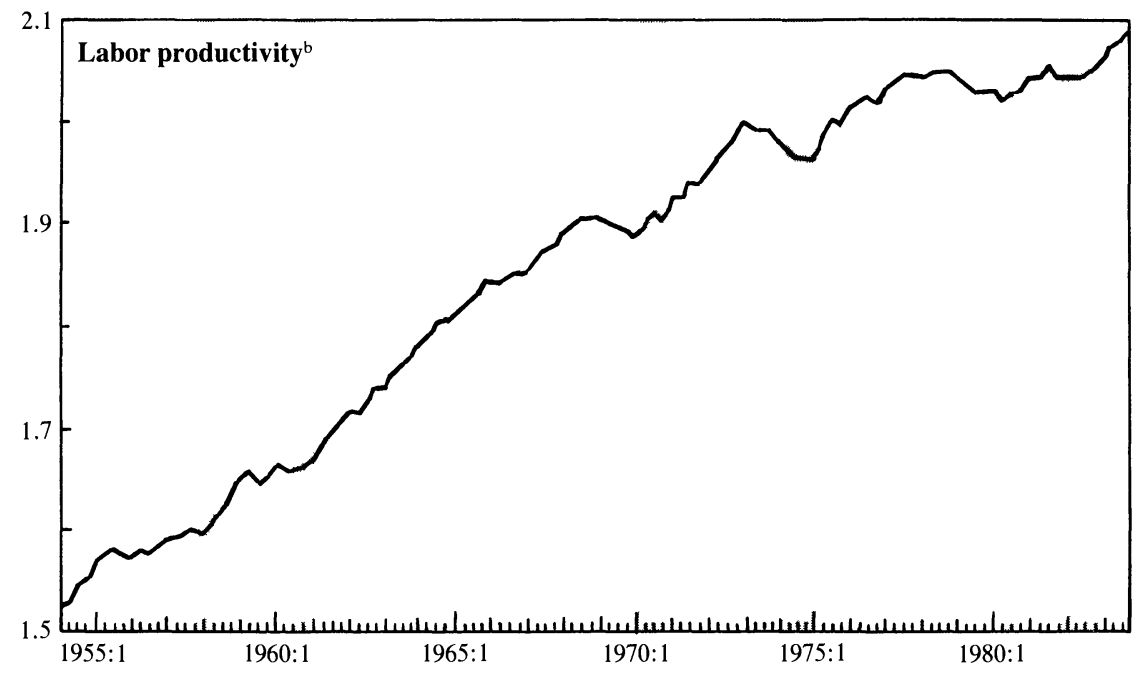

Percent

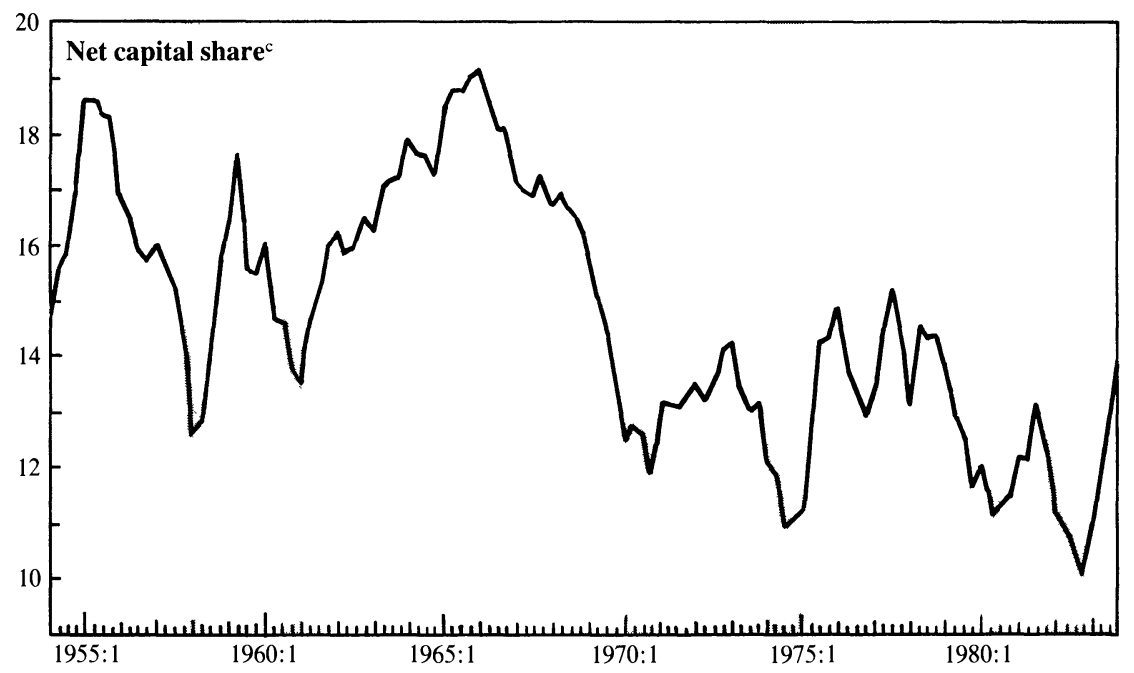

Source: U.S. Bureau of Economic Analysis and U.S. Bureau of Labor Statistics.

a. Shaded areas indicate periods of recession.

b. Private nonfarm business sector.

c. Economic profits before taxes plus interest as a percent of gross domestic product, nonfinancial corporate business sector. 
from changes in the margin between prices and standard unit labor cost-compensation per hour divided by trend productivity. Consequently, in the discussion below, the difference between the price level and standard unit labor cost will be examined as an intermediate link between productivity and profits. Indirect business taxes and depreciation also add to the cyclical variation in the net capital share. Neither is sensitive to output in the short run, ${ }^{5}$ so as output increases, their share of the total declines.

Table 1 provides a close-up view of labor productivity, price-cost margins, and the net capital share in the vicinity of business cycle peaks and troughs. It compares the data for the recent recession and recovery with the historical range of performance for the previous postwar cycles. Between 1981:3 and 1982:3, labor productivity fell only 0.6 percent, substantially less than the decline of 2.5 percent in 1973-74; however, in the six recessions before 1973, productivity usually grew in the year following the business cycle peak. In the year after the business cycle trough in 1982, labor productivity growth was fairly strong in absolute terms but certainly not by historical standards; the rise of 3.3 percent is smaller than in any of the six postwar recoveries before 1980. Even productivity performance in the first half of 1983 was not outstanding; it rose 2.6 percent, compared with 4.1 percent in the first two quarters of recovery in 1975 .

The price-cost margin fell unusually fast in the last quarters of the 1981-82 recession, as shown in table 1. This could be construed as evidence that the productivity growth trend has improved, but given the data on labor productivity discussed above, it seems more likely to be related to the extraordinary depth of the downturn or the strength of the dollar. Since the end of 1982, the price-cost margin has remained constant-right in line with historical experience. During the first year of six previous recoveries, the price-cost margin fell four times and rose twice.

Recent movements in the net income from capital follow a pattern that is consistent with the behavior of productivity and price-cost margins. Given the margin squeeze just noted, the decline in capital's

5. Depreciation is a slowly changing fraction of the capital stock, so it is not sensitive to short-term fluctuations in output. Indirect business taxes include some items that are not a function of output (such as real estate taxes) and taxes on other items, such as crude oil and gasoline, that are not very cyclical. 


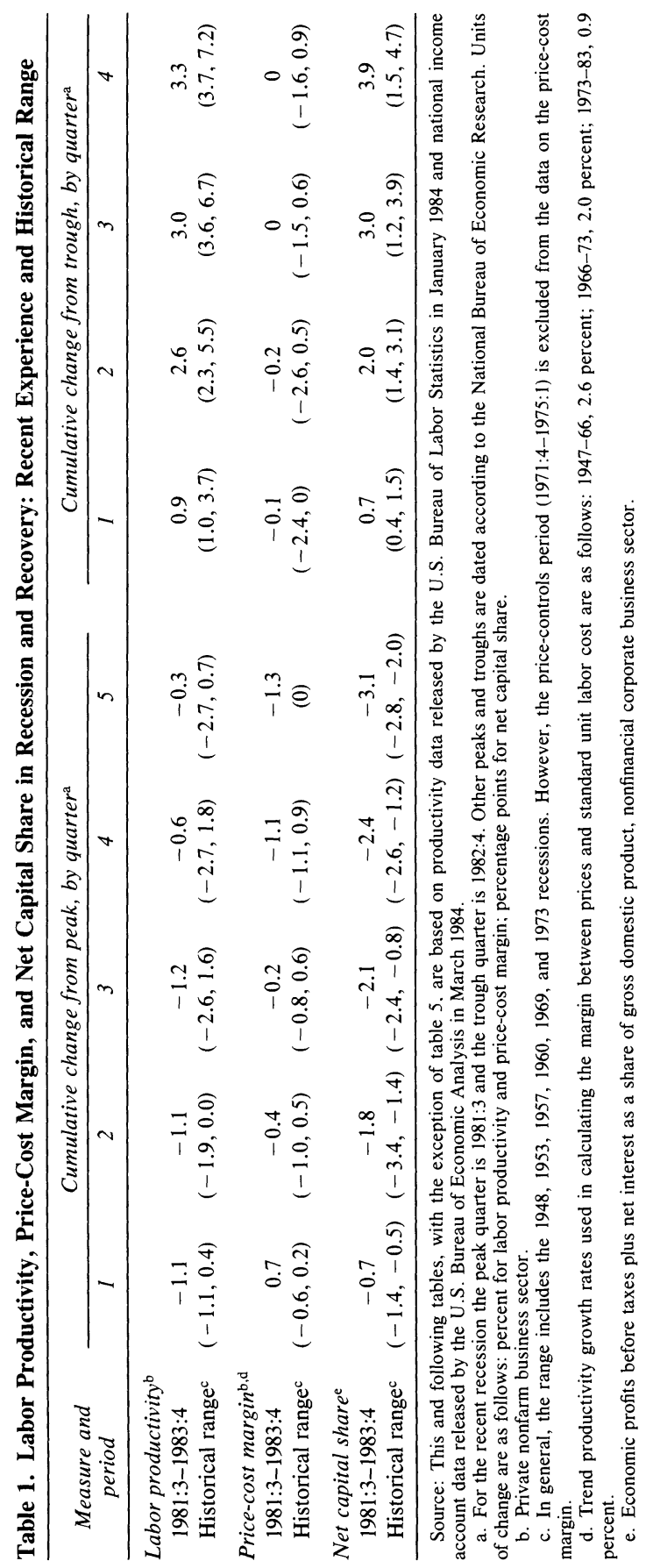


share should also be larger than usual; indeed, it was more precipitous than that recorded in any other postwar recession. The profit recovery after 1982:4 is very strong, producing a recovery in the capital share comparable to 1958-59 and at the high end of the historical range; but given the 1981-82 decline, it is hard to tell whether the rebound is signaling a change in underlying trends or just eliminating an earlier aberration.

Overall, the data in table 1 reveal no major trend shifts in productivity or profits since mid-1981. The recent recovery in productivity appears rather weak by historical standards and seems to offset the slightly better than average performance during the last half of 1982. And the strong rebound of income from capital in 1983 may be only offsetting the steep decline in 1981-82. However, different business cycles have different characteristics; rough cyclical comparisons can obscure effects that are related to the severity of different recessions and the strength of different recoveries. In the following section a simple econometric model of cyclical productivity and capital income behavior is proposed, and its theoretical foundation is discussed; in succeeding sections its parameters are estimated, and the model is used to examine underlying trends in productivity and profits.

\section{A Partial-Adjustment Model of Productivity, Price-Cost Margins, and the Net Income from Capital}

Cyclical variations in labor input arise as a reaction to the cyclical movement of real output, and most prices are closely related to costs, possibly with some adjustment for the pressure of demand. Thus the cyclical behavior of productivity and capital income can be analyzed using a model with three equations:

$$
\begin{gathered}
\log \left(1-D_{t}-T_{t}-P R_{t}\right)=\left[W_{t}-\left(Y_{t}-H_{t}\right)\right]-P_{t} \\
H_{t}=a H_{t-1}+(1-a) H_{t}^{*}+u_{t} \\
P_{t}=c P_{t-1}+(1-c) P_{t}^{*}+v_{t},
\end{gathered}
$$

where

$$
\begin{aligned}
& P=\text { the } \log \text { of the price level } \\
& Y=\text { the } \log \text { of real output }
\end{aligned}
$$


$W=$ the $\log$ of compensation per hour

$H=$ the $\log$ of hours of labor input

$P R=$ economic profits and net interest as a share of output

$T=$ indirect business taxes as a share of output

$D=$ depreciation (valued at replacement cost) as a share of output

$u, v=$ disturbance terms

$*$ = the target value of a variable (as discussed later in the text).

Equation 2 is merely a rearranged version of identity 1 ; it says that the log of labor's share of output equals the log of unit labor cost, $\left[W_{t}-\right.$ $\left(Y_{t}-H_{t}\right)$ ], minus the log of the price level, $P_{t}$.

Equations 3 and 4 are the behavioral equations in the system for labor input and for the price level, respectively. Each is a partial-adjustment model in which the dependent variable (either $H_{t}$ or $P_{t}$ ) is adjusted part of the way between its value in the previous period and a target value for the current period.

In the case of labor input, $H_{t}$, such a partial-adjustment model arises from assuming that the cost of deviating from desired labor input, $\boldsymbol{H}_{t}^{\prime}$, in any given period and the cost of adjusting labor input from one period to the next are both quadratic. The sum of these two costs in each period is then

$$
C_{t}=A\left(H_{t}-H_{t-1}\right)^{2}+B\left(H_{t}-H_{t}^{\prime}\right)^{2} .
$$

The dynamic optimization problem facing each firm in the economy at time $t$ can be given as:

$$
\text { Minimize }\left(E_{t} \sum_{s=0}^{\infty} R^{s} C_{t+s}\right) \text { with respect to } H_{t}, H_{t+1}, \ldots,
$$

where $R$ is a discount factor less than one. Since $C_{t}$ is quadratic, the principle of first period certainty equivalence can be employed, ${ }^{6}$ yielding the following solution:

$$
H_{t}-a H_{t-1}=(1-a)(1-b) \sum_{s=0}^{\infty} b^{s} E_{t} H_{t+s}^{\prime},
$$

where $a<1$ and $\mathrm{b}<1$ are parameters that depend on the relative cost coefficients $A$ and $B$ and the discount factor $R \cdot{ }^{7}$ In the simplest case,

6. See Herbert A. Simon, "Dynamic Programming Under Uncertainty with a Quadratic Criterion Function," Econometrica, vol. 24 (January 1956), pp. 74-81.

7. Quadratic adjustment cost models for labor input have a long history dating back at 
desired labor input is assumed to be output divided by the underlying trend in productivity, but more complex formulations can also be used. Note that equation 6 implies that $H_{t}^{*}$ in equation 3 can be expressed as follows:

$$
H_{t}^{*}=(1-b) \sum_{s=0}^{\infty} b^{s} E_{t} H_{t+s}^{\prime},
$$

where the target value for hours is a geometrically weighted average of current and expected future values of optimal labor input. As the adjustment cost rises relative to the cost of deviation from optimal input (that is, $A / B$ increases), the coefficients $a$ and $b$ both increase, and guessing the right value of future optimal input becomes more important; firms want hours to be in the right place in the future so they can avoid changing them. Conversely, if adjustment costs become negligible, $a$ and $b$ both decrease, and adjustment is nearly complete in one period. Firms can ignore future desired inputs because the cost of adjusting to any new desired level is fairly small. If expectations are static, and the current level of $H_{t}^{\prime}$ is expected to persist into the future, then $H_{t}^{*}=H_{t}^{\prime}$ and

$$
H_{t}-a H_{t-1}=(1-a) H_{t}^{\prime}+u_{t} .
$$

In the less restrictive case where expectations are assumed to be "forward-looking," equation 6 can be estimated only after a reasonable representation of $E_{t} H_{t+s}^{\prime}$ is found.

With the same sort of adjustment-cost assumption for the price level, formulas similar to equations 6 and 7 can be derived:

$$
\begin{gathered}
P_{t}-c P_{t-1}=(1-c) P_{t}^{*} \\
P_{t}^{*}=(1-\mathrm{d}) \sum_{s=0}^{\infty} d^{s} E_{t} P_{t+s}^{\prime} .
\end{gathered}
$$

The parameters $c$ and $d$ again depend on relative adjustment cost and

least to Charles C. Holt and others, Planning Production, Inventories and Work Force (Prentice-Hall, 1960). More recent work includes Christoper A. Sims, "Output and Labor Input in Manufacturing," BPEA, 3:1974, pp. 695-728; Thomas J. Sargent, "Estimation of Dynamic Labor Demand Schedules Under Rational Expectations," Journal of Political Economy, vol. 86 (December 1978), pp. 1009-44; and John Kennan, "The Estimation of Partial Adjustment Models with Rational Expectations," Econometrica, vol. 47 (November 1979), pp. 1441-55. 
the discount factor used, and the price target is again a geometrically weighted average of "desired" prices expected in the future. Under the (unrealistic) assumptions that the current price level is expected to prevail in the future $\left(E_{t} P_{t+s}^{\prime}=P_{t}^{\prime}\right)$ and that adjustment of the price level is not very costly, equation 8 (with the addition of the usual disturbance term) becomes:

$$
P_{t}=P_{t}^{\prime}+v_{t} \text {. }
$$

If the desired price level $P_{t}^{\prime}$ is a function of standard unit labor cost (measured as hourly compensation divided by the trend in labor productivity), materials prices, and demand pressures, equation $10 \mathrm{implies}$ that the price level is determined by a markup over costs, with the markup varying over the business cycle. In first-differenced form, equation 10 is similar to the "structural" inflation equations estimated by a number of authors. ${ }^{8}$ If the expected future price level is different from the currentperiod price level, then the expression for $P_{t}^{*}$ is more complicated and contains future expected cost increases. The weight of expected future costs in the price target depends on the cost of price adjustment; as in the case of labor demand, if adjustment is expensive, prices should be smooth relative to input costs and follow them with a substantial lag. Conversely, if prices are easy to adjust, they should follow costs fairly closely.

I now turn to the estimation of equations 6 and 8 , using them to construct cyclical adjustments for labor productivity, price-cost margins, and net income from capital.

\section{Cyclical Behavior and Underlying Trends in Labor Productivity}

While the theory of labor demand discussed above implies a simple partial adjustment of hours to a moving target of desired hours as indicated in equation 6 , estimation of this equation is complicated by the fact that both the desired number of labor hours in any given time period,

8. For instance, see Otto Eckstein, ed., The Econometrics of Price Determination (Board of Governors of the Federal Reserve System, 1972); Charles L. Schultze, "Falling Profits, Rising Profit Margins, and the Full Employment Profit Rate," BPEA, 2:1975, pp. 449-71; and Robert J. Gordon, "Can the Inflation of the 1970s Be Explained?' BPEA, 1:1977, pp. 257-77. 
$H_{t}^{\prime}$, and previous expectations about $H_{t}^{\prime}$ are unobservable. To resolve the problem, equation 6 has been estimated under a number of assumptions about $H_{t}^{*}$, the target value of labor input at time $t$. If static expectations are assumed, then the target value $H_{t}^{*}$ is taken to be current output divided by the trend level of productivity, so $H_{t}^{*}=Y_{t}-f(t)$, where $f(t)$ is a broken-line trend for the log of trend productivity. This yields the regression equation

$$
\begin{aligned}
\Delta H_{t}= & a_{1}\left(Y_{t}-H_{t-1}\right)-a_{1} a_{0}-a_{1} a_{2}(\text { TIME })-a_{1} a_{3}(T 66) \\
& -a_{1} a_{4}(T 73)-a_{1} a_{5}(T 79)-a_{1} a_{6}(T 83) \\
& -a_{1} a_{7}\left(Y_{t}-Y P_{t}\right)+u_{t},
\end{aligned}
$$

where $T I M E$ is a time trend $(1,2,3, \ldots)$ running throughout the data period. The other time trends start as follows: T66 in 1966:4; T73 in 1973:4; $T 79$ in 1979:4; and $T 83$ in 1983:1. The variable $Y P_{t}$ is the $\log$ of potential output in the private nonfarm sector based on an unemployment benchmark that is 4.5 percent in 1955 and rises gradually to 6 percent in 1978. When expectations are assumed to be forward-looking, $H_{t}^{*}$ is given by equation 7 , and the implied regression is virtually identical to equation 11 with $Y_{t}^{*}=(1-b) \sum_{s=0}^{\infty} b^{s} E_{t} Y_{t+s}$ substituted for $Y_{t} \cdot{ }^{9}$

In either case, the $a_{i}$ coefficients have the following interpretations: $a_{1}$ is the partial-adjustment coefficient, or the fraction of desired total adjustment of hours completed in one quarter; $a_{0}$ and $a_{2}$ through $a_{6}$ are coefficients on the (log of the) trend level of productivity. The $a_{7}$ coefficient allows the level of productivity used in the labor input target to change over the business cycle, reflecting output mix effects: if cyclically sensitive industries have higher than average labor productivity, then the hours target should be relatively low when these industries are near capacity, and relatively high when a higher proportion of total output is produced in other sectors.

In table 2, expectations are assumed to be static, so that equation 11 is estimated directly. The first and third columns, which have no output gap term $\left(Y_{t}-Y P_{t}\right)$, show no increase in trend labor productivity either since the end of 1979 or the beginning of 1983. With the output gap

9. Equation 11 with $Y_{t}^{*}$ replacing $Y_{t}$ is only an approximation to the correct regression in the forward-looking expectations case. A distributed lead on $f(t)$ should be included, but this generates a highly nonlinear estimation equation. Since $f(t)$ moves smoothly over time, future $f(t)$ terms can be included in the constant $a_{1} a_{0}$. 
Table 2. Regressions for Changes in Labor Hours Assuming Static Expectations ${ }^{\text {a }}$

\begin{tabular}{|c|c|c|c|c|c|c|c|}
\hline \multicolumn{2}{|r|}{ Coefficient } & \multicolumn{4}{|c|}{$1954: 1-1983: 4$} & \multicolumn{2}{|c|}{$1954: 1-1979: 3$} \\
\hline$a_{1}$ & $\begin{array}{l}\text { Partial adjustment } \\
\text { to output }\end{array}$ & $\begin{array}{c}0.485 \\
(0.032)\end{array}$ & $\begin{array}{c}0.563 \\
(0.046)\end{array}$ & $\begin{array}{c}0.489 \\
(0.033)\end{array}$ & $\begin{array}{c}0.559 \\
(0.050)\end{array}$ & $\begin{array}{c}0.461 \\
(0.036)\end{array}$ & $\begin{array}{c}0.518 \\
(0.049)\end{array}$ \\
\hline$a_{2}$ & $\begin{array}{l}\text { Trend productivity } \\
\text { growth rate }\end{array}$ & $\begin{array}{c}2.63 \\
(0.20)\end{array}$ & $\begin{array}{l}2.58 \\
(0.22)\end{array}$ & $\begin{array}{l}2.63 \\
(0.21)\end{array}$ & $\begin{array}{l}2.59 \\
(0.22)\end{array}$ & $\begin{array}{c}2.63 \\
(0.23)\end{array}$ & $\begin{array}{c}2.58 \\
(0.25)\end{array}$ \\
\hline$a_{3}$ & $\begin{array}{l}\text { Trend change } \\
\text { in } 1966: 4^{b}\end{array}$ & $\begin{array}{r}-0.65 \\
(0.21)\end{array}$ & $\begin{array}{c}-0.57 \\
(0.18)\end{array}$ & $\begin{array}{c}-0.64 \\
(0.21)\end{array}$ & $\begin{array}{c}-0.59 \\
(0.20)\end{array}$ & $\begin{array}{c}-0.65 \\
(0.22)\end{array}$ & $\begin{array}{c}-0.57 \\
(0.17)\end{array}$ \\
\hline$a_{4}$ & $\begin{array}{l}\text { Trend change } \\
\text { in } 1973: 4^{b}\end{array}$ & $\begin{array}{c}-1.12 \\
(0.30)\end{array}$ & $\begin{array}{c}-1.12 \\
(0.27)\end{array}$ & $\begin{array}{c}-1.17 \\
(0.24)\end{array}$ & $\begin{array}{c}-1.04 \\
(0.20)\end{array}$ & $\begin{array}{c}-1.07 \\
(0.33)\end{array}$ & $\begin{array}{c}-1.05 \\
(0.27)\end{array}$ \\
\hline$a_{5}$ & $\begin{array}{l}\text { Trend change } \\
\text { in } 1979: 4^{b}\end{array}$ & $\begin{array}{r}-0.10 \\
(0.46)\end{array}$ & $\begin{array}{c}0.27 \\
(0.42)\end{array}$ & . & $\ldots$ & . & $\cdots$ \\
\hline$a_{6}$ & $\begin{array}{l}\text { Trend change } \\
\text { in } 1983: 1^{\mathrm{b}}\end{array}$ & . & . & $\begin{array}{c}0.22 \\
(1.41)\end{array}$ & $\begin{array}{c}0.55 \\
(1.20)\end{array}$ & & \\
\hline$a_{7}$ & Output gap effect ${ }^{\mathrm{c}}$ & . & $\begin{array}{c}0.172 \\
(0.063)\end{array}$ & . & $\begin{array}{c}0.161 \\
(0.061)\end{array}$ & & $\begin{array}{c}0.157 \\
(0.068)\end{array}$ \\
\hline & $\begin{array}{c}\text { mmary statistic } \\
\text { Standard error } \\
\text { of estimate }\end{array}$ & 0.45 & 0.43 & 0.45 & 0.43 & 0.44 & 0.43 \\
\hline & $R^{2}$ & 0.80 & 0.82 & 0.80 & 0.82 & 0.80 & 0.81 \\
\hline & Rho & 0.65 & 0.66 & 0.66 & 0.65 & 0.64 & 0.61 \\
\hline
\end{tabular}

Source: Equation 11.

a. Private nonfarm business sector. Numbers in parentheses are standard errors.

b. Percent per year, obtained by multiplying regression coefficients and standard errors on trend variables by 400 .

c. Percent change in target productivity level, from a 1 percentage point change in $Y / Y P$.

included in the second and fourth columns, thus allowing for output-mix effects, the results are a little more optimistic; they show an increase of 0.25 percent per year starting in 1980 , or 0.5 percent per year starting in 1983. However, the $t$-statistic for each of these changes is about $0.5-$ not very convincing evidence that any substantial improvement has taken place. It should also be noted that the output gap measure included in the second and fourth columns is based on a benchmark unemployment rate of 6 percent; with a higher unemployment benchmark, the average ratio of actual to potential output would be smaller in 1980-83, and the estimated trend growth rate for productivity would be reduced.

In all the regressions in table 2 , the estimated autocorrelation coefficient of the residuals is about 0.65 and the partial-adjustment coefficient is about 0.5 . Without the autocorrelation adjustment, the partial-adjustment coefficient falls to about 0.4 . Autocorrelated errors may have been generated by the rough (broken line) approximation to the trend in productivity; for example, if the trend growth rate was not quite constant 
between 1954 and 1966, serially correlated residuals would have been generated even if partial adjustment was the correct model.

The relatively low partial-adjustment coefficients in table 2 suggest that adjustment costs are high enough to make expected future output important in current hours decisions if firms have forward-looking rather than static expectations. To investigate this possibility, $E_{t} Y_{t+s}$ was approximated with forecasts derived from a simple second-order autoregression representation for the output gap: ${ }^{10}$

$$
Y_{t}-Y P_{t}=1.44\left(Y_{t-1}-Y P_{t-1}\right)-0.48\left(Y_{t-2}-Y P_{t-2}\right)+w_{t} .
$$

Forecasts of future output are then assumed to be based on equation 12; that is, ${ }^{11}$

$$
\begin{aligned}
& E_{t} Y_{t+1}=Y P_{t+1}+1.44\left(Y_{t}-Y P_{t}\right)-0.48\left(Y_{t-1}-Y P_{t-1}\right) \\
& E_{t} Y_{t+2}=Y P_{t+2}+1.44\left(E_{t} Y_{t+1}-Y P_{t+1}\right)-0.48\left(Y_{t}-Y P_{t}\right) .
\end{aligned}
$$

$Y_{t}^{*}$ can then be approximated by

$$
Y_{t}^{*} \simeq \frac{1}{\text { const }} \sum_{s=0}^{4} b^{s} E_{t} Y_{t+s}
$$

if $b$ is not too large ( $b$ is slightly smaller than one minus the partialadjustment coefficient, or about 0.5 , to begin with). ${ }^{12}$

10. Potential output $Y P_{t}$ in the private nonfarm sector was estimated as a slowly rising fraction of potential gross national product over time. The potential GNP series is similar to the ones in Peter K. Clark, "A Kalman Filtering Approach to the Estimation of Potential GNP"' (Yale University, November 1983).

11. A consensus of economic forecasts from the American Statistical AssociationNational Bureau of Economic Research survey of forecasters was substituted for the forecasts from equation 12 , but the results changed very little. This is probably because simple time series models forecast about as well as the standard econometric services. See Charles R. Nelson, "A Benchmark for the Accuracy of Economic Forecasts of GNP," Working Paper 11 (University of Washington, Center for the Study of Banking and Financial Markets, 1983).

12. To make the coefficients in the sum for $E_{t} Y_{t+s}$ consistent with the partial-adjustment coefficient obtained in the regression, it is necessary to iterate by first forming the sum with an initial guess, then doing the regression to find a new partial-adjustment coefficient to use in the sum, and so forth. This process converges in only two or three iterations. 
Table 3. Regressions for Changes in Labor Hours Assuming Forward-looking Expectations $^{\mathrm{a}}$

\begin{tabular}{lccccccc}
\hline & Coefficient & \multicolumn{3}{c}{$1954: 1-1983: 4$} & & \multicolumn{2}{c}{$1954: 1-1979: 3$} \\
\hline$a_{1} \quad$ Partial adjustment & 0.383 & 0.387 & 0.384 & 0.385 & 0.370 & 0.372 \\
& to output & $(0.024)$ & $(0.028)$ & $(0.025)$ & $(0.029)$ & $(0.027)$ & $(0.032)$ \\
$a_{2} \quad$ Trend productivity & 2.57 & 2.57 & 2.58 & 2.58 & 2.57 & 2.57 \\
$\quad$ growth rate & $(0.18)$ & $(0.20)$ & $(0.18)$ & $(0.20)$ & $(0.21)$ & $(0.23)$ \\
$a_{3} \quad$ Trend change & -0.57 & -0.57 & -0.59 & -0.59 & -0.58 & -0.57 \\
$\quad$ in 1966:4 & $(0.16)$ & $(0.16)$ & $(0.16)$ & $(0.16)$ & $(0.18)$ & $(0.18)$ \\
$a_{4} \quad$ Trend change & -1.15 & -1.15 & -1.07 & -1.07 & -1.11 & -1.11 \\
$\quad$ in 1973:4 & $(0.24)$ & $(0.24)$ & $(0.19)$ & $(0.19)$ & $(0.27)$ & $(0.27)$ \\
$a_{5} \quad$ Trend change & 0.19 & 0.21 & $\ldots$ & $\ldots$ & $\ldots$ & $\ldots$ \\
$\quad$ in 1979:4 & $(0.37)$ & $(0.40)$ & & & & \\
$a_{6} \quad$ Trend change & $\ldots$ & $\ldots$ & 0.14 & 0.15 & $\ldots$. & $\ldots$ \\
$\quad$ in 1983:1 & & & $(1.38)$ & $(1.40)$ & & \\
$a_{7} \quad$ Output gap effect & $\ldots$ & 0.015 & $\ldots$ & 0.004 & $\ldots$ & 0.009 \\
$\quad$ Summary statistic & & $(0.060)$ & & $(0.058)$ & & $(0.067)$ \\
Standard error & & & & & & \\
$\quad$ of estimate & 0.43 & 0.43 & 0.43 & 0.43 & 0.43 & 0.43 \\
$R^{2} \quad$ & 0.82 & 0.82 & 0.82 & 0.82 & 0.81 & 0.81 \\
Rho & 0.44 & 0.44 & 0.45 & 0.45 & 0.45 & 0.45 \\
\hline
\end{tabular}

Source: Equations 11 and 12 . See discussion in text.

a. See table 2, notes a-c.

This procedure gives the "forward-looking expectations" results in table 3. Not surprisingly, since the target value for hours includes (higher) future values, the partial-adjustment coefficient falls from 0.5 to about 0.4 . The output gap term essentially disappears; this suggests that an alternative to output-mix effects for explaining low productivity at low levels of capacity utilization is that firms expect output to rise in the future and therefore employ more hours than they would if they had expected output to remain permanently low.

Forward-looking expectations may also explain Gordon's end-ofexpansion overhiring effect. ${ }^{13}$ If firms are perennially optimistic in the

13. See Robert J. Gordon, "The 'End-of-Expansion Phenomenon' in Short-Run Productivity Behavior,' $B P E A, 2: 1979$, pp. 447-61. Gordon found that during the last half of the expansion phase of most business cycles, labor input gradually rises to a level about 2 percent above its predicted value. This excess is then worked off in the subsequent recession and recovery. The partial-adjustment model used in this paper cuts the end-ofexpansion effect to about 1 percent but does not eliminate it. 
period before a recession, they will tend to overhire and reduce productivity. This sort of "overshooting expectations" is implicit in responses to the capital spending surveys of both the U.S. Commerce Department and McGraw-Hill: businessmen almost always overestimate future investment immediately before a recession and underestimate future investment during a recovery.

Estimates of a recent change in the trend growth rate of productivity are uniformly small in table 3, strengthening the conclusion that there has been little or no shift in the rate of fundamental efficiency gain. However, the standard error for a change in trend productivity growth at the beginning of 1983 is 1.5 percentage points, implying that one year's data are insufficient for discovering a change in trend.

All cyclical adjustments rely on history repeating itself. If firms did less labor hoarding during the 1980 or 1981-82 recessions, then more of the recent productivity gain would be trend and less would be cyclical rebound. The regressions in table 4 investigate this possibility together with the possibility that a more significant trend shift might be found if it were dated starting in 1981:3, just before the recession deepened, rather than in 1979:4. ${ }^{14}$ No significant rise in the partial-adjustment coefficient is found, either at the end of 1979 or in the middle of 1981, as shown by the insignificant coefficients in the second and third rows. Evidently, labor input did not react to output any faster in the 1980s than it had in the past, so it is unlikely that less of the recent productivity surge is cyclical. Furthermore, the estimated change in trend productivity growth remains both statistically and arithmetically small when the change is allowed to start in 1981:3, as in the eighth row of the table.

\section{Recent Productivity Movements}

In view of the statistical evidence in tables 2 through 4 that no important change has occurred, what caused the recent wave of optimism about productivity? In part it may have come from the rise in actual

14. Note that if the partial-adjustment coefficient $a_{1}$ is allowed to change, then the time trend coefficients $a_{1} a_{0}, a_{1} a_{2}$, and so on, must change in a consistent way. This nonlinearity in estimation was again resolved by iteration. The change in $a_{1}$ was estimated assuming constant values for $a_{1} a_{0}, a_{1} a_{2}$, and so on. Then the implied change in these coefficients was plugged into TIME $, T 66, \ldots$, and the change in $a_{1}$ was re-estimated. Given the small value for the change in $a_{1}$, this process converges in two iterations. 
Table 4. Alternative Post-1979 Hypotheses in Labor-Hours Regressions, 1954:1-1983:4a

\begin{tabular}{|c|c|c|c|c|c|}
\hline & Coefficient & $\begin{array}{r}\text { Static } \\
\text { with }\end{array}$ & $\begin{array}{l}\text { tations } \\
\text { it gap } \\
t\end{array}$ & $\begin{array}{l}\text { Forwa } \\
\text { expe }\end{array}$ & $\begin{array}{l}\text { ooking } \\
\text { ions }\end{array}$ \\
\hline$a_{1}$ & $\begin{array}{l}\text { Partial adjustment } \\
\text { to output }\end{array}$ & $\begin{array}{c}0.559 \\
(0.046)\end{array}$ & $\begin{array}{c}0.556 \\
(0.046)\end{array}$ & $\begin{array}{c}0.385 \\
(0.024)\end{array}$ & $\begin{array}{c}0.382 \\
(0.024)\end{array}$ \\
\hline$a_{1}^{\prime}$ & $\begin{array}{l}\text { Change in adjustment } \\
\text { coefficient in 1979:4 }\end{array}$ & $\begin{array}{c}0.001 \\
(0.002)\end{array}$ & 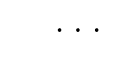 & $\begin{array}{c}0.001 \\
(0.002)\end{array}$ & $\ldots$ \\
\hline$a_{1}^{\prime \prime}$ & $\begin{array}{l}\text { Change in adjustment } \\
\text { coefficient in 1981:3 }\end{array}$ & . & $\begin{array}{r}-0.001 \\
(0.002)\end{array}$ & . & $\begin{array}{r}-0.002 \\
(0.002)\end{array}$ \\
\hline$a_{2}$ & $\begin{array}{l}\text { Trend productivity } \\
\text { growth rate }\end{array}$ & $\begin{array}{l}2.58 \\
(0.22)\end{array}$ & $\begin{array}{l}2.58 \\
(0.22)\end{array}$ & $\begin{array}{l}2.58 \\
(0.18)\end{array}$ & $\begin{array}{l}2.57 \\
(0.18)\end{array}$ \\
\hline$a_{3}$ & Trend change in $1966: 3$ & $\begin{array}{c}-0.57 \\
(0.17)\end{array}$ & $\begin{array}{c}-0.56 \\
(0.17)\end{array}$ & $\begin{array}{l}-0.58 \\
(0.16)\end{array}$ & $\begin{array}{c}-0.56 \\
(0.16)\end{array}$ \\
\hline$a_{4}$ & Trend change in $1973: 4$ & $\begin{array}{c}-1.08 \\
(0.27)\end{array}$ & $\begin{array}{c}-1.14 \\
(0.23)\end{array}$ & $\begin{array}{r}-1.10 \\
(0.25)\end{array}$ & $\begin{array}{c}-1.18 \\
(0.21)\end{array}$ \\
\hline$a_{5}$ & Trend change in 1979:4 & $\begin{array}{c}0.32 \\
(0.42)\end{array}$ & . & $\begin{array}{c}0.26 \\
(0.40)\end{array}$ & $\cdots$ \\
\hline$a_{5}^{\prime}$ & Trend change in $1981: 3$ & . & $\begin{array}{c}0.42 \\
(0.65)\end{array}$ & $\ldots$ & $\begin{array}{c}0.04 \\
(0.70)\end{array}$ \\
\hline$a_{7}$ & Output gap effect & $\begin{array}{l}0.172 \\
(0.06)\end{array}$ & $\begin{array}{l}1.177 \\
(0.06)\end{array}$ & $\cdots$ & $\cdots$ \\
\hline & mmary statistic & & & & \\
\hline & $\begin{array}{l}\text { tandard error } \\
\text { of estimate } \\
2^{2} \\
\text { Rho }\end{array}$ & $\begin{array}{l}0.43 \\
0.82 \\
0.63\end{array}$ & $\begin{array}{l}0.43 \\
0.82 \\
0.65\end{array}$ & $\begin{array}{l}0.43 \\
0.82 \\
0.43\end{array}$ & $\begin{array}{l}0.43 \\
0.82 \\
0.43\end{array}$ \\
\hline
\end{tabular}

Source: Table 2, second and fourth columns, and table 3, first and third columns. a. See table 2 , notes a-c.

productivity of the past several quarters. In the last half of 1982, productivity improved even though output was still falling, an event that first kindled hopes that the abysmal productivity performance of the 1970s had finally ended. Then in the first three quarters of 1983 , productivity rose at the rate of 4.5 percent per year, reinforcing the optimism that had emerged the previous year.

However, the comparison in table 5 of actual productivity with projections from the equation in the fifth column of table 3 indicates that both these productivity spurts are short run in character. The projections assume the productivity trend starting in 1979:4 is 1.0 percent per year, 0.15 percentage points higher than the trend rate estimated for 1974-79. Although productivity rose faster in the last half of 1982 than projected, 
Table 5. Actual and Projected Labor Hours and Labor Productivity Growth, 1981:1-1984:1

\begin{tabular}{|c|c|c|c|c|c|c|}
\hline \multirow[b]{3}{*}{$\begin{array}{l}\text { Year and } \\
\text { quarter }\end{array}$} & \multirow{2}{*}{\multicolumn{3}{|c|}{$\begin{array}{c}\text { Labor hours } \\
\text { (billion hours per year) }\end{array}$}} & \multicolumn{3}{|c|}{$\begin{array}{l}\text { Productivity growth } \\
\text { (percent per year) }\end{array}$} \\
\hline & & & & & & Difference \\
\hline & Actual & Projected & $\begin{array}{c}\text { Difference } \\
\text { (percent) }\end{array}$ & Actual & Projected & $\begin{array}{l}\text { (percent- } \\
\text { age points) }\end{array}$ \\
\hline 1981:1 & 147.9 & 146.3 & 1.1 & 5.1 & 4.4 & 0.8 \\
\hline 2 & 148.1 & 146.7 & 0.9 & 0.4 & -0.3 & 0.7 \\
\hline 3 & 148.2 & 147.6 & 0.4 & 3.8 & 1.9 & 1.9 \\
\hline 4 & 146.7 & 146.4 & 0.2 & -4.5 & -5.3 & 0.8 \\
\hline 1982:1 & 144.4 & 144.9 & -0.4 & 0.1 & -2.2 & 2.3 \\
\hline 2 & 144.8 & 144.3 & 0.3 & -0.4 & 2.5 & -2.8 \\
\hline 3 & 143.7 & 143.7 & 0.0 & 2.3 & 1.1 & 1.2 \\
\hline 4 & 141.8 & 142.6 & -0.5 & 1.3 & -1.0 & 2.3 \\
\hline 1983:1 & 142.2 & 142.7 & -0.4 & 3.5 & 4.3 & -0.8 \\
\hline 2 & 144.4 & 144.7 & -0.2 & 7.1 & 7.5 & -0.4 \\
\hline 3 & 146.6 & 146.6 & 0.0 & 2.3 & 3.1 & -0.8 \\
\hline 4 & 148.4 & 148.5 & 0.1 & 2.7 & 2.4 & 0.3 \\
\hline 1984:1 & 151.0 & 150.9 & 0.1 & 2.6 & 3.0 & -0.4 \\
\hline
\end{tabular}

Source: Projections based on coefficients in fifth column of table 2, starting in 1979:4, with 1.0 percent per year 1980-84 trend productivity growth assumed. Data for last two quarters from BLS productivity data released April 1984.

the extra increase partly offset the exceptionally poor performance in the second quarter of the year. One possible explanation is that many firms believed that the recession had ended early in $1982^{15}$ and therefore began to increase labor input; when output continued downward, another round of layoffs ensued, raising productivity because output declines were tapering off. In 1983, productivity gains were reasonably strong, though actually smaller than might have been expected, and they were below expectations again in the first quarter of 1984. Since the third quarter of 1983, labor input has just matched the level projected by the equation, which uses an underlying productivity trend of 1.0 percent per year.

Productivity optimism may also have arisen because of changes in factors that have often been blamed for the productivity slowdown. The baby boom generation is now well on its way to being assimilated by the

15. For example, the Economic Report of the President, February 1982 said that "At the time this Report was prepared [January 1982], it appeared that the recession which started in August ... will be over by the second quarter of 1982"' (p. 25). This was in line with most commercially available forecasts. 
labor market, inflation is declining, energy prices have stabilized, and substantial incentives for plant modernization and new research and development were put in place in 1981. So the stage seems to be set for stronger productivity performance. But emphasis should be placed on the word seems because none of the voluminous literature on the productivity slowdown can account for even half of the total slowdown after 1973;16 if the factors cited cannot account for the disappearance of productivity growth, their abatement should not be expected to produce its reappearance. On the other hand, if some combination of the factors listed above did contribute importantly to the slowdown, their reversal should have produced some improvement in the underlying trend of productivity growth. Optimists might argue that these factors are all secular in nature and that more than two or three years may be needed for changes in them to affect productivity. For example, high inflation rates (and the high variance of relative prices that goes with them) may have reduced the rate of productivity growth by diverting management attention away from real efficiency gains and toward "paper entrepreneurship" - financial innovation to take advantage of price instability. ${ }^{17}$ The fact that the inflation rate has declined substantially and productivity growth has not improved would not eliminate this possibility, because it could take a long time for firms to turn their attention back to physical efficiency improvement. The same sort of timing argument would apply to demographic factors, research and development, and particularly capital stock growth, which slowed substantially as a consequence of the 1981-82 recession. Nonetheless, if these factors did contribute to the slowdown, their improvement should have produced at least some rise in the productivity trend, time lags notwithstanding; apparently they have not.

\section{Price-Cost Margins and the Business Cycle}

The income from capital has a strong cyclical component that is related both to the cyclical movement in labor productivity and to any changes in the margin between output price and standard unit labor cost.

16. See Denison, Accounting for Slower Economic Growth.

17. See Peter K. Clark, "Inflation and the Productivity Decline," American Economic Review, vol. 72 (May 1982, Papers and Proceedings, 1981), pp. 149-54. 
Therefore an examination of the cyclical behavior of price-cost margins is a necessary intermediate step in the cyclical adjustment of income from capital. A substantial amount of research has been done on the cyclical behavior of markups; many authors have investigated inflation equations similar to equation 10 . Most of these studies have found either no effect or only a small effect of demand pressure on prices once labor costs have been taken into account. For example, Nordhaus and Godley found that the business cycle had little or no effect on markups in the United Kingdom between 1954 and 1968, and Schultze concluded that excess capacity had little effect on margins in the United States between the mid-1950s and the mid-1970s. ${ }^{18}$ Such findings seem roughly consistent with the cyclical comparison data in table 1 , which showed no discernible effect of the business cycle on the price-cost margin. However, Gordon has found a variety of demand effects that influence price markups; for example, in 1977 he concluded that a decline in output that increased the gap between potential and actual gross national product by 1 percentage point would reduce the inflation rate by 0.2 percentage points over a period of two years, holding labor and materials costs constant. ${ }^{19}$

The magnitude of this "price-cost squeeze" coefficient is important in the cyclical adjustment of income from capital. If it is negligible, then an examination of profits in the 1980s requires no allowance for the substantial amount of slack that has persisted for the last four years. On the other hand, if Gordon's estimate is correct and the "no squeeze" unemployment rate is 6 percent, then the price level has been reduced approximately 4 percent by the cumulative excess unemployment since the beginning of 1980 . Such a reduction would have a major impact on the net capital share.

\section{MARGINS IN NONFARM BUSINESS}

The specific form of equation 8 used to estimate the price-cost squeeze effect is similar to the regression equation for productivity. Assuming that $P_{t}^{*}=S_{t}^{*}+g(t)$, so that the target value for the log of the price level is a combination of present and future standard unit labor costs, $S_{t}^{*}$, plus the markup as a function of time, $g(t)$, yields:

18. William D. Nordhaus and Wynne Godley, "Pricing in the Trade Cycle," Economic Journal, vol. 82 (September 1972), pp. 853-82, and Schultze, "Falling Profits."

19. Gordon, "Can the Inflation of the 1970s Be Explained?" 


$$
\begin{aligned}
\Delta P_{t}= & b_{1}\left(S_{t}^{*}-P_{t-1}\right)+b_{1} b_{0}+b_{1} b_{2}(T I M E)+b_{1} b_{3}(T 65) \\
& +b_{1} b_{4}(T 71)+b_{1} b_{5}(T 79)+b_{1} \Sigma c_{s}\left(Y_{t-s}-Y P_{t-1}\right) \\
& +b_{1} b_{6} D_{o t}+b_{1} b_{7} D_{c t}+u_{t},
\end{aligned}
$$

where $P_{t}=\log$ of the price level (as before), $S_{t}^{*}=\Sigma d^{s} E_{t} S_{t+s}$, a weighted average of the log of current and expected future standard unit labor costs $S_{t}$, and TIME is a time trend $(1,2,3, \ldots)$ running throughout the data period. The other time trends start as follows: T65 in 1965:1; T71 in 1971:1; and $T 79$ in 1979:4. The variable $D_{o t}$ is the oil price dummy: 0.0 before $1974: 2$, rising linearly to 1.0 in $1975: 1$, then falling linearly to 0.0 in 1977:1, and 0.0 thereafter. The variable $D_{c t}$ is the price control dummy: 0.0 before $1971: 4$; rising linearly to 1.0 in $1973: 1,1.0$ from $1973: 1$ to $1974: 1$, then falling to 0.0 in $1975: 1 .^{20}$ When price adjustment costs are negligible, $b_{1}=1$ and $S_{t}^{*}$ is merely the log of current standard unit labor cost, or compensation per hour divided by the trend level of productivity. If prices are allowed to adjust more slowly to labor cost, then $S_{t}^{*}$ is the log of current standard unit labor cost plus an adjustment for expected future cost inflation.

Regression estimates of equation 13 are given in table 6 for the private nonfarm business sector deflator. The price-cost squeeze term, in the seventh line of table 6 , is uniformly small in each regression, with the coefficient on output gaps half its standard error or less, indicating that the level of demand affects the rate of price inflation only indirectly through the wage rate. Thus, it appears that only a small cyclical adjustment to the net capital share will be required for the price-cost squeeze effect.

The other regression variables in table 6 are all dummies or time trends that have no structural significance. However, they do provide a convenient characterization of changes in the price-cost margin over the last 30 years. The coefficient of the price controls dummy, in the ninth row, indicates that the imposition of price controls depressed the price level about 2 percent relative to labor costs from 1971:4 through 1973:1, and that their removal after early 1974 raised the price level by an equal amount. This symmetry is imposed by the form of the dummy variable. ${ }^{21}$

20. The variable $D_{c t}$ is the integral of the price controls dummy used by Gordon in "Can the Inflation of the 1970s Be Explained?" Integration is required because equation 13 is an equation for the price level rather than for the inflation rate.

21. Gordon, in "Can the Inflation of the 1970s Be Explained?" estimated a similar 
Table 6. Regressions for the Private Nonfarm Business Sector Deflator ${ }^{\text {a }}$

\begin{tabular}{|c|c|c|c|c|c|}
\hline \multirow{2}{*}{\multicolumn{2}{|c|}{ Coefficient }} & \multicolumn{2}{|c|}{$1954: 1-1983: 4$} & \multicolumn{2}{|c|}{$1954: 1-1979: 3$} \\
\hline & & $\begin{array}{c}\text { Partial } \\
\text { adjustment } \\
\text { uncon- } \\
\text { strained }\end{array}$ & $\begin{array}{c}\text { Partial } \\
\text { adjustment } \\
\text { constrained } \\
\text { to } 1.0\end{array}$ & $\begin{array}{c}\text { Partial } \\
\text { adjustment } \\
\text { uncon- } \\
\text { strained }\end{array}$ & $\begin{array}{c}\text { Partial } \\
\text { adjustment } \\
\text { constrained } \\
\text { to } 1.0\end{array}$ \\
\hline$b_{1}$ & $\begin{array}{l}\text { Partial adjustment } \\
\text { to labor costs }\end{array}$ & $\begin{array}{c}1.14 \\
(0.10)\end{array}$ & $\begin{array}{l}1.0 \\
\ldots\end{array}$ & $\begin{array}{l}1.13 \\
(0.10)\end{array}$ & $\begin{array}{l}1.0 \\
\ldots\end{array}$ \\
\hline$b_{0}$ & Constant term & $\begin{array}{c}0.407 \\
(0.041)\end{array}$ & $\begin{array}{c}0.403 \\
(0.012)\end{array}$ & $\begin{array}{c}0.399 \\
(0.039)\end{array}$ & $\begin{array}{c}0.398 \\
(0.007)\end{array}$ \\
\hline$b_{2}$ & Trend starting 1954:1 & $\begin{array}{c}0.097 \\
(0.098)\end{array}$ & $\begin{array}{c}0.123 \\
(0.080)\end{array}$ & $\begin{array}{c}0.144 \\
(0.055)\end{array}$ & $\begin{array}{c}0.156 \\
(0.048)\end{array}$ \\
\hline$b_{3}$ & Trend change in $1965: 1$ & $\begin{array}{c}-0.388 \\
(0.183)\end{array}$ & $\begin{array}{c}-0.422 \\
(0.165)\end{array}$ & $\begin{array}{c}-0.441 \\
(0.117)\end{array}$ & $\begin{array}{c}-0.452 \\
(0.106)\end{array}$ \\
\hline$b_{4}$ & Trend change in $1971: 1$ & $\begin{array}{c}0.025 \\
(0.163)\end{array}$ & $\begin{array}{c}0.049 \\
(0.157)\end{array}$ & $\begin{array}{c}0.030 \\
(0.114)\end{array}$ & $\begin{array}{c}0.021 \\
(0.109)\end{array}$ \\
\hline$b_{5}$ & Trend change in $1979: 4$ & $\begin{array}{c}0.452 \\
(0.233)\end{array}$ & $\begin{array}{c}0.453 \\
(0.228)\end{array}$ & $\ldots$ & $\ldots$ \\
\hline$\Sigma c_{\mathrm{s}}$ & Sum of output gaps ${ }^{b}$ & $\begin{array}{c}0.017 \\
(0.039)\end{array}$ & $\begin{array}{c}0.024 \\
(0.041)\end{array}$ & $\begin{array}{c}0.003 \\
(0.032)\end{array}$ & $\begin{array}{c}0.006 \\
(0.032)\end{array}$ \\
\hline$b_{6}$ & Oil price dummy & $\begin{array}{c}0.025 \\
(0.006)\end{array}$ & $\begin{array}{c}0.026 \\
(0.006)\end{array}$ & $\begin{array}{c}0.026 \\
(0.005)\end{array}$ & $\begin{array}{c}0.028 \\
(0.005)\end{array}$ \\
\hline$b_{7}$ & Price controls dummy & $\begin{array}{c}-0.022 \\
(0.005)\end{array}$ & $\begin{array}{l}-0.021 \\
(0.005)\end{array}$ & $\begin{array}{r}-0.020 \\
(0.005)\end{array}$ & $\begin{array}{r}-0.019 \\
(0.004)\end{array}$ \\
\hline \multicolumn{6}{|c|}{ Summary statistic } \\
\hline & $\begin{array}{l}\text { andard error } \\
\text { of estimate }\end{array}$ & 0.0036 & 0.0036 & 0.0032 & 0.0032 \\
\hline$R^{2}$ & & 0.95 & 0.95 & 0.96 & 0.96 \\
\hline $\mathrm{Rh}$ & & 0.82 & 0.77 & 0.74 & 0.67 \\
\hline
\end{tabular}

Source: Equation 13.

a. See table 2 , notes a and $b$.

b. Sum of unconstrained coefficients in current and four lagged quarters; units are percent change in price level resulting from a 1 percentage point change in $Y / Y P$.

The time trend coefficients indicate that prices fell relative to standard unit labor costs by nearly 0.3 percentage points per year between 1965 and 1979. More recently, however, price-cost margins seem to be rising by about 0.2 percentage points per year. Given the income shares identity (equation 1 or 2), these trends should be reflected in the income from capital.

downward dip of 2 percent. Alan S. Blinder and William J. Newton found a deflection of 3 or 4 percent in "The 1971-1974 Controls Program and the Price Level: An Econometric Post-Mortem," Journal of Monetary Economics, vol. 8 (July 1981), pp. 1-23. 


\section{MARGINS EXCLUDING OIL AND GAS}

The estimates in table 6 are less than satisfactory in at least two respects. First, oil price effects are captured only with a dummy variable, and competition from foreign imports is ignored altogether. ${ }^{22}$ In an attempt to remedy these shortcomings, equation 13 was reestimated using a deflator for the private nonfarm business sector excluding domestic oil and natural gas production. ${ }^{23}$ With the effect of oil and gas prices removed, it is possible to explore the effect of other import prices on domestic price margins. This is done by including the Commerce Department's unit value index for nonpetroleum imports on the righthand side of equation 13 to capture a "competing goods" effect. ${ }^{24}$ The regression results are given in table 7 . The output gap coefficients are insignificant and arithmetically small and have the wrong sign. This supports the finding from table 6 that there is no price-cost squeeze effect discernible in the data.

The "competing goods" coefficient on import prices has the correct sign but is small. The estimate is greatly influenced by events since exchange rates started moving over a wide range. The relative price of imports rose substantially after the shift to floating exchange rates in 1973, which helps explain the bulge in price-cost margins in that period. In 1976-78 the relative price of imports stayed high, but the price-cost margin fell. This episode holds down the "import competition" coefficient. ${ }^{25}$ In any case, any reasonable estimate of this coefficient implies only slight effects on the U.S. inflation rate. For example, between the end of 1979 and the end of 1982, the price of non-oil imports fell about

22. Recently Gordon has emphasized the importance of the external sector in price determination. See his "Inflation, Flexible Exchange Rates, and the Natural Rate of Unemployment," in Martin Neil Baily, ed., Workers, Jobs, and Inflation (Brookings Institution, 1982), pp. 89-152.

23. To adjust the deflator for changes in crude oil and natural gas prices in 1974-75 and 1979-80, domestic output of crude oil and natural gas in current and constant dollars was estimated and then subtracted from current- and constant-dollar private nonfarm output. The ratio of these "ex oil and gas" output figures gives a value-added deflator that excludes oil and gas bulges, assuming a one-for-one passthrough of oil and gas costs in the prices of finished goods.

24. Because a value-added deflator is being used, the direct effect of import prices (for raw materials or component parts) is already excluded. However, imports compete directly with domestically produced goods in a number of sectors and may play a role in determining domestic prices.

25. In "Inflation, Flexible Exchange Rates," Gordon estimates an exchange rate 
Table 7. Regressions for the Private Nonfarm Business Sector Deflator Excluding Production of Crude Petroleum and Natural Gas ${ }^{\mathrm{a}}$

\begin{tabular}{|c|c|c|c|c|c|}
\hline \multirow{2}{*}{\multicolumn{2}{|c|}{ Coefficient }} & \multicolumn{2}{|c|}{$1956: 3-1983: 4$} & \multicolumn{2}{|c|}{$1956: 3-1979: 3$} \\
\hline & & $\begin{array}{c}\text { Partial } \\
\text { adjustment } \\
\text { uncon- } \\
\text { strained }\end{array}$ & $\begin{array}{c}\text { Partial } \\
\text { adjustment } \\
\text { constrained } \\
\text { to } 1.0\end{array}$ & $\begin{array}{c}\text { Partial } \\
\text { adjustment } \\
\text { uncon- } \\
\text { strained }\end{array}$ & $\begin{array}{c}\text { Partial } \\
\text { adjustment } \\
\text { constrained } \\
\text { to } 1.0\end{array}$ \\
\hline$b_{1}$ & $\begin{array}{l}\text { Partial adjustment } \\
\text { to labor costs }\end{array}$ & $\begin{array}{l}1.09 \\
(0.10)\end{array}$ & $\begin{array}{l}1.0 \\
\ldots\end{array}$ & $\begin{array}{c}1.08 \\
(0.10)\end{array}$ & $\begin{array}{c}1.0 \\
\ldots\end{array}$ \\
\hline$b_{0}$ & Constant term & $\begin{array}{c}0.405 \\
(0.038)\end{array}$ & $\begin{array}{c}0.390 \\
(0.015)\end{array}$ & $\begin{array}{c}0.397 \\
(0.040)\end{array}$ & $\begin{array}{c}0.387 \\
(0.016)\end{array}$ \\
\hline$b_{2}$ & Trend starting $1956: 3$ & $\begin{array}{c}0.088 \\
(0.112)\end{array}$ & $\begin{array}{l}0.176 \\
(0.095)\end{array}$ & $\begin{array}{c}0.137 \\
(0.106)\end{array}$ & $\begin{array}{c}0.193 \\
(0.106)\end{array}$ \\
\hline$b_{3}$ & Trend change in $1965: 1$ & $\begin{array}{c}-0.165 \\
(0.191)\end{array}$ & $\begin{array}{c}-0.255 \\
(0.165)\end{array}$ & $\begin{array}{c}-0.202 \\
(0.182)\end{array}$ & $\begin{array}{c}-0.261 \\
(0.180)\end{array}$ \\
\hline$b_{4}$ & Trend change in $1971: 1$ & $\begin{array}{c}-0.594 \\
(0.200)\end{array}$ & $\begin{array}{c}-0.678 \\
(0.191)\end{array}$ & $\begin{array}{c}-0.740 \\
(0.195)\end{array}$ & $\begin{array}{c}-0.758 \\
(0.199)\end{array}$ \\
\hline$b_{5}$ & Trend change in $1979: 4$ & $\begin{array}{c}0.290 \\
(0.289)\end{array}$ & $\begin{array}{c}0.387 \\
(0.286)\end{array}$ & $\cdots$ & . \\
\hline$\Sigma c_{\mathrm{s}}$ & Sum of output gaps ${ }^{b}$ & $\begin{array}{c}-0.023 \\
(0.043)\end{array}$ & $\begin{array}{c}-0.051 \\
(0.048)\end{array}$ & $\begin{array}{c}-0.041 \\
(0.042)\end{array}$ & $\begin{array}{c}-0.053 \\
(0.045)\end{array}$ \\
\hline$b_{7}$ & Price controls dummy & $\begin{array}{r}-0.027 \\
(0.005)\end{array}$ & $\begin{array}{c}-0.024 \\
(0.005)\end{array}$ & $\begin{array}{c}-0.027 \\
(0.005)\end{array}$ & $\begin{array}{r}-0.026 \\
(0.005)\end{array}$ \\
\hline$b_{8}$ & Non-oil import prices ${ }^{c}$ & $\begin{array}{c}0.018 \\
(0.021)\end{array}$ & $\begin{array}{c}0.037 \\
(0.023)\end{array}$ & $\begin{array}{l}0.048 \\
(0.022)\end{array}$ & $\begin{array}{c}0.053 \\
(0.025)\end{array}$ \\
\hline \multicolumn{6}{|c|}{ Summary statistic } \\
\hline & $\begin{array}{l}\text { andard error } \\
\text { of estimate }\end{array}$ & 0.0040 & 0.0040 & 0.0037 & 0.0037 \\
\hline$R$ & & 0.97 & 0.98 & 0.98 & 0.97 \\
\hline $\mathrm{R}$ & & 0.77 & 0.71 & 0.79 & 0.75 \\
\hline
\end{tabular}

Source: Equation 13

a. See table 2 , notes a and b.

b. See table 6 , note b.

c. Regressor is the log of (unit value index for non-oil imports divided by the "ex oil plus gas" deflator), so a coefficient of 0.1 indicates that a 10 percent rise in the relative price of non-oil imports raises domestic non-oil prices by 1 percent.

15 percent relative to the price of private nonfarm output in the United States. The coefficient of 0.04 in the second column of table 7 implies that this relative import-price decline reduced the level of the domestic price deflator by 0.6 percent spread over four years; a coefficient as large as 0.1 would imply a reduction of 1.5 percent, which is still small when

coefficient of about 0.1 in a reduced-form equation for prices. Substantial differences between his equations and those in table 7 make it unclear whether the two results are consistent. 
compared to the 30 percent rise in non-oil prices over those four years. However, such a change would represent a noticeable movement in the price-wage margin.

The time trend coefficients differ between tables 6 and 7, revealing the effect of energy prices in the table 6 estimates. In particular, much of the upward trend in the aggregate price-cost margin since the end of 1979 can be attributed to the second OPEC price shock and the decontrol of oil and gas prices. As table 7 shows, when oil and gas are removed from the domestic value-added deflator, the estimated trend in the pricecost markup for the remainder of nonfarm business remains negative (about -0.4 percent per year). The trends over different subperiods are shown below for the equation in the second columns of tables 6 and 7 .

\begin{tabular}{ccc} 
& \multicolumn{2}{c}{ Percent per year } \\
\cline { 2 - 3 } & \multicolumn{2}{c}{ Nonfarm business } \\
& ex oil and gas \\
$1956: 3-1964: 4$ & 0.12 & 0.18 \\
$1965: 1-1970: 4$ & -0.30 & -0.08 \\
$1971: 1-1979: 3$ & -0.25 & -0.76 \\
$1979: 4-1983: 4$ & 0.20 & -0.37
\end{tabular}

It should be emphasized that the import competition and oil price effects discussed above, as well as the slow drift of the price level relative to standard unit labor cost captured in the time-trend dummies in tables 6 and 7, are very small compared with the strong association of prices with labor cost. As shown in figure 2, changes in the price deflator can be closely approximated by changes in standard unit labor cost. (Figure 2 would be virtually unchanged if the "ex oil and gas" deflator had been plotted instead of the unadjusted deflator.) The difference between the two series is largely unsystematic, which explains why it is difficult to find large price-cost squeeze and import competition influences. Given the weak and unstable effect of the business cycle on the ratio of the price deflator to standard unit labor cost, adjustment of the price-cost margin is not required when capital's share of output is adjusted for the business cycle in the following section.

\section{The Cyclical and Secular Behavior of Capital's Share of Output}

The implied cyclical adjustment of capital's net share of output is given by the differential of equation 2 : 
Figure 2. Changes in Price Deflator and Standard Unit Labor Cost, Private Nonfarm Business Sector, 1954:1 to 1983:4

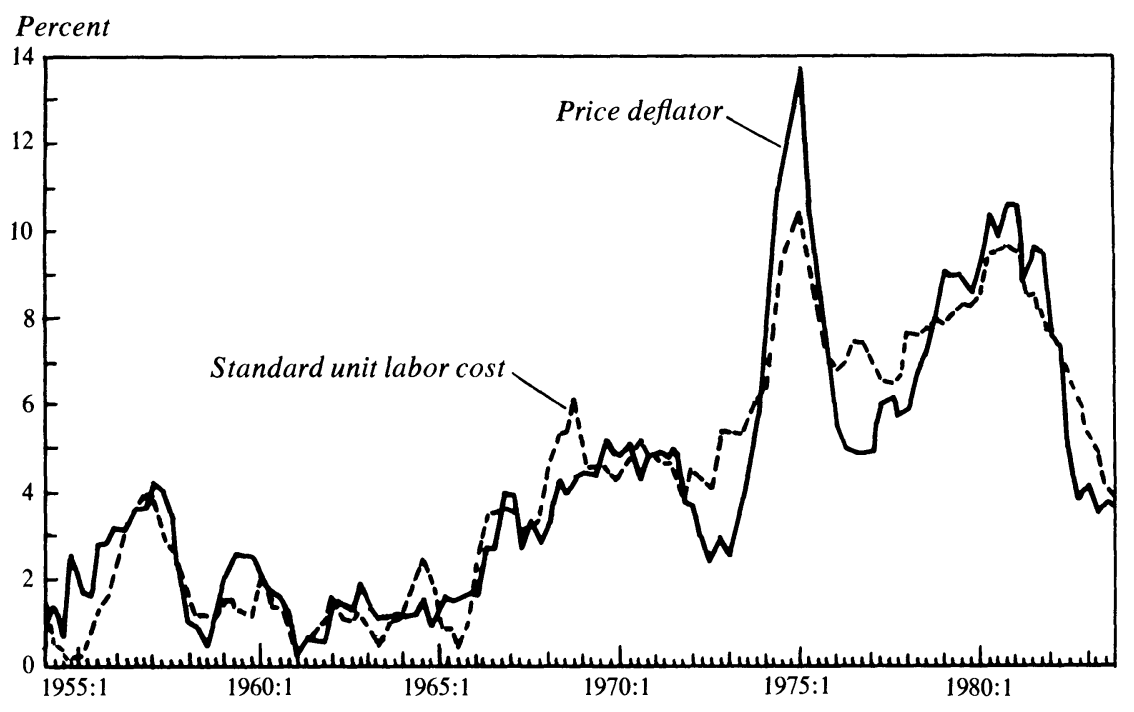

Source: Same as figure 1 .

a. Change over four quarters.

(14) $\mathrm{d} P R=-\mathrm{d} D-\mathrm{d} T+(1-D-T-P R)[\mathrm{d}(P-W)+\mathrm{d}(Y-H)]$.

Cyclical variations around trend are small enough for equation 14 to be a reasonable approximation; it says that cyclical movements in the net capital share $(P R)$ are the sum of four terms: the cyclical variations in the depreciation share, the indirect business tax share, labor productivity, and the price-cost margin. When output increases relative to trend, $D$ and $T$ both decline, productivity increases, and the price-cost margin is not affected significantly. Thus only the first three terms are empirically important and all have the same sign.

The cyclical adjustments for economic depreciation and indirect business taxes are estimated by assuming that neither is affected by the business cycle (note 5$)$, so $\mathrm{d} D=D(Y P / Y-1)$ and $\mathrm{d} T=T(Y P / Y-1)$. The adjustment for cyclical movement in labor productivity is calculated by comparing estimates of productivity at potential and actual output derived from the regression coefficients in the third column of table 3. As indicated by equation 14, this difference has to be multiplied by labor's share of output. 
Table 8. Net Capital Share of Gross Domestic Product, Nonfinancial Corporations, 1981-1983 $^{\text {a }}$

Percent

\begin{tabular}{rcccccc}
\hline & & \multicolumn{4}{c}{ Adjustment for cyclical variation } & \\
\cline { 3 - 5 } $\begin{array}{c}\text { Year and } \\
\text { quarter }\end{array}$ & $\begin{array}{c}\text { Net capital } \\
\text { share }\end{array}$ & $\begin{array}{c}\text { Depreciation } \\
\text { share }\end{array}$ & $\begin{array}{l}\text { Indirect tax } \\
\text { share }\end{array}$ & $\begin{array}{c}\text { Labor } \\
\text { productivity }\end{array}$ & $\begin{array}{c}\text { Total } \\
\text { cyclical } \\
\text { adjustment }\end{array}$ & $\begin{array}{c}\text { Cyclically } \\
\text { adjusted net } \\
\text { capital share }\end{array}$ \\
\hline $1981: 1$ & 12.1 & 0.39 & 0.37 & 0.15 & 0.91 & 13.0 \\
2 & 12.1 & 0.49 & 0.43 & 0.38 & 1.30 & 13.4 \\
3 & 13.0 & 0.43 & 0.40 & 0.24 & 1.07 & 14.1 \\
4 & 12.3 & 0.77 & 0.68 & 1.28 & 2.73 & 15.0 \\
$1982: 1$ & 11.2 & 1.04 & 0.90 & 1.81 & 3.75 & 15.0 \\
2 & 10.9 & 1.12 & 0.95 & 1.57 & 3.64 & 14.5 \\
3 & 10.6 & 1.24 & 1.05 & 1.57 & 3.86 & 14.5 \\
4 & 9.9 & 1.46 & 1.24 & 1.90 & 4.60 & 14.5 \\
$1983: 1$ & 10.7 & 1.39 & 1.21 & 1.37 & 3.97 & 14.7 \\
2 & 11.9 & 1.10 & 1.00 & 0.31 & 2.41 & 14.3 \\
3 & 12.9 & 0.95 & 0.87 & -0.03 & 1.79 & 14.7 \\
4 & 13.8 & 0.86 & 0.79 & -0.04 & 1.61 & 15.4 \\
\hline
\end{tabular}

Source: U.S. Bureau of Economic Analysis and cyclical adjustment procedure described in text. a. Net capital income is economic profits before taxes plus net interest payments.

The effect of these cyclical adjustments for the period 1981-83 is shown in table 8. On an unadjusted basis, the net capital share-beforetax economic profits plus net interest divided by gross domestic product-dropped 3.1 percentage points in the 1981-82 recession, reaching a record low in 1982:4. About 1.7 percentage points of this decline can be attributed to the productivity weakness that accompanied the recession, while 1.9 percentage points come from the added share of output allocated to cyclically insensitive depreciation and indirect business taxes as the output base is reduced, bringing the total estimated effect of the recession to 3.5 percentage points. Thus, net income from capital fell a little less than expected, given the steep output decline that occurred, and the cyclically adjusted capital share actually rose during the $1981-82$ recession.

From 1982:4 to $1983: 4$ the net capital share rose 3.9 percentage points, of which 1.9 points can be attributed to the cyclical upturn in productivity and another 1.1 points to the decline in the tax and depreciation share. The cyclically adjusted net capital share rose 0.9 percentage points further in the first four quarters of recovery, to a level of 15.4 percent. That level is higher than the average of 14 percent that prevailed during the 1970s but still well below the 16 to 17 percent of the 1950 s and $1960 \mathrm{~s}$. 
Figure 3. Actual and Adjusted Net Capital Share, Nonfinancial Corporate Business Sector, 1954:1 to $1983: 4^{a}$

Percent

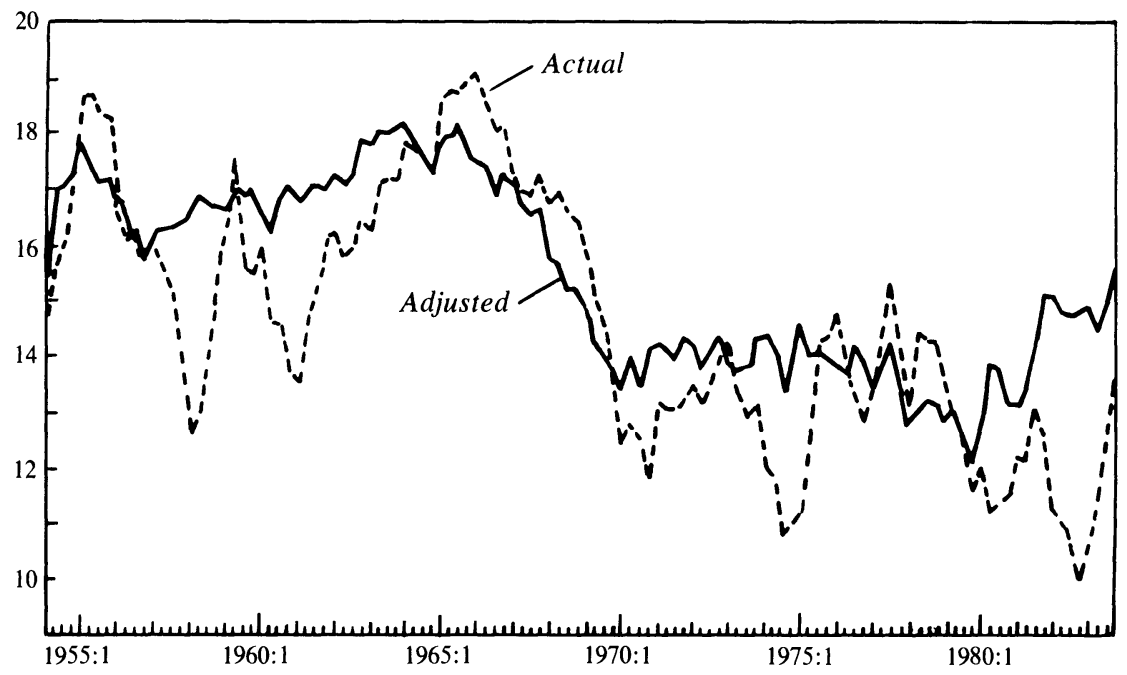

Source Actual share from U.S. Bureau of Economic Analysis. Adjusted share calculated by using equation in second column of table 6 to remove estimated effects of business cycle, price controls, and first OPEC oil price shock

Thus, it appears that profits have been slowly improving in the 1980s but not as much as might be inferred by looking at the raw data for 1983 . Data are not available for calculating the capital share excluding the oil and natural gas sectors, so it is not possible to sort out the effects of changing energy prices (including the effects of the second world oil price shock and decontrol of domestic oil prices) from the net capital share as a whole.

The reasons for the marked decline in capital's share in the last half of the 1960s and its partial rebound in the 1980s remain unclear. ${ }^{26}$ As shown in figure 3, after cyclical adjustment the decline appears as a slide extending from the mid-1960s to the early 1970s. Since this is the same period in which the inflation rate climbed rapidly and labor productivity growth began to slow, figure 3 suggests that the profit decline may be linked to rising inflation or slowing productivity growth.

None of the hypotheses that tie the decline in capital's share to the

26. See Martin Feldstein and Lawrence Summers, "Is the Rate of Profit Falling?" BPEA, 1:1977, pp. 211-27, and Feldstein, "The Effective Tax Rate." 
Table 9. Net Capital Share, Depreciation, and Capital Gains on Debt, Nonfinancial Corporations, 1954-83

Percent

\begin{tabular}{|c|c|c|c|}
\hline Years & $\begin{array}{c}\text { Cyclically } \\
\text { adjusted net } \\
\text { capital share }\end{array}$ & $\begin{array}{l}\text { Replacement } \\
\text { cost minus book } \\
\text { depreciation as } \\
\text { a share of } \\
\text { gross domestic } \\
\text { product }\end{array}$ & $\begin{array}{c}\text { Capital gains } \\
\text { on long-term } \\
\text { liabilities as } \\
\text { a share of } \\
\text { gross domestic } \\
\text { product }^{\mathrm{a}}\end{array}$ \\
\hline $1954-59$ & 16.7 & 1.6 & 1.3 \\
\hline $1960-64$ & 17.3 & -0.1 & -0.4 \\
\hline $1965-69$ & 16.3 & -0.8 & 2.7 \\
\hline $1970-74$ & 14.0 & -0.2 & -0.1 \\
\hline $1975-79$ & 13.5 & -1.0 & 1.1 \\
\hline $1980-83$ & 14.2 & 0.1 & 0.8 \\
\hline
\end{tabular}

Source: For first and second columns, same as table 8; for percentage capital gain on long-term Treasury bonds as used in third column, Roger G. Ibbotson and Rex A. Sinquefield, Stocks, Bonds, Bills, and Inflation: The Past and the Future (Charlottesville, Va.: The Financial Analysts Research Foundation, 1983).

a. Capital gains calculated by multiplying year-end long-term debt outstanding (from Federal Reserve flow-offunds accounts) by the percentage capital gain on a long-term Treasury bond portfolio.

increase in inflation or to the decline in productivity growth is completely satisfactory, but some are better than others. For example, it could be argued that markups were based on historical-cost depreciation or the historical cost of borrowing (that is, the capital gains from unexpected reductions in the real value of indebtedness were passed through to customers), leading to a decline in margins calculated on a replacement cost basis, as they are in figure 3 . However, the data in table 9 show that neither the difference between replacement cost and book depreciation (the second column) nor the capital gains on nonfinancial corporations' long-term indebtedness (the third column) are large enough, or timed properly, to explain the variations in the net capital share. The maximum difference between replacement cost and book depreciation in table 9 is only 1 percent of output, and for only one five-year interval (1975-79). Capital gains on long-term liabilities are large enough to explain most of the net capital share decline in the last half of the 1960s, but they do not explain why capital income stayed low in the 1970s. Substantial capital gains on long-term debt would have had to extend through the 1970s to make total income from capital (including capital gains) equal to pre1965 levels. Nor can the profit squeeze be explained by changes in the taxation of capital if it is assumed that the after-tax return to capital 
stayed fixed, because it is generally agreed that the tax burden on income from capital went up, not down, in the late 1960s and early 1970s. ${ }^{27}$

One conjecture that at least roughly fits the facts is that longer-run movements in income shares are determined by the relative scarcity of labor resources. Generally tight labor market conditions in the late $1960 \mathrm{~s}$ and early 1970s could have shifted the balance of power in favor of labor, cutting into capital's share. This new division of output prevailed until the determination to reduce inflation even at the risk of protracted high unemployment started moving the balance of power back toward capital in the 1980s. The mid-1970s downturn might have been ineffective in changing the climate for income-share determination because the recovery was relatively rapid, and economic policy was explicitly aimed at returning to high levels of output with less attention paid to inflation..$^{28}$ Back-to-back recessions in the early 1980s could have had more of an effect on the labor market climate, ${ }^{29}$ explaining the apparent rise in capital's share.

This "longer-run labor scarcity" argument is at least consistent with, and may even help explain, the slowdown in labor productivity growth. Tight labor markets could have reduced efficiency growth by moving less qualified workers into critical jobs and stiffened labor's resistance to technological change, thus contributing to the decline in growth of output per hour of labor input. ${ }^{30} \mathrm{Or}$, if productivity growth declined for some other reason, demand for labor would have been increased, keeping labor markets tight.

27. See Feldstein, "The Effective Tax Rate," or Mervyn A. King and Don Fullerton, eds., The Taxation of Income From Capital: A Comparative Study of the United States, the United Kingdom, Sweden, and West Germany (University of Chicago Press, 1983).

28. The unemployment rate hit 9 percent in May 1975, but the recovery was relatively rapid. Less than three years later the Carter administration had pushed the unemployment rate below 6 percent and inflation was again on the upswing. This observation is also consistent with those of Thomas E. Weisskopf, Samuel Bowles, and David M. Gordon, who found that the cost of job loss did not rise significantly in the mid-1970s, an indication that labor was still scarce; see their "Hearts and Minds: A Social Model of U.S. Productivity Growth," BPEA, 2:1983, pp. 381-441.

29. See Robert J. Flanagan, "Wage Concessions and Long-Term Union Wage Flexibility," $B P E A$, this issue.

30. In "Hearts and Minds," Weisskopf, Bowles, and Gordon use the term "declining work intensity" to describe a general deterioration of workplace cooperation in the late 1960 s, to which they attribute much of the productivity slowdown. 
In any case, the facts seem to be fairly clear: while most of the 1983 profit rebound is cyclical, there does seem to be some increase in the underlying share of output accruing to capital. On a cyclically adjusted basis, capital's net share fell from 17 percent of output in the 1950s and early 1960 s to 14 percent during the 1970 s. Starting in 1980 , its share has started to rise, reaching 15.4 percent by the end of last year. A part of this rebound, particularly in 1980 and 1981, may have come from the rise in the price of domestically produced oil and gas. But part, especially in 1983, may reveal a recovery in the capital share in the rest of the nonfarm economy.

\section{Conclusion}

The encouraging performance of both productivity and profits over the last year or two is, to an important extent, a cyclical reaction to the end of the long 1980-82 decline in output and the strong economic rebound in 1983. Once the estimated effect of the cycle has been removed, the underlying trend in labor productivity growth has been about 1 percent per year since 1979, nearly the same rate as in the 1970s and only half the long-run average (since 1890) of about 2 percent per year.

The apparent lack of improvement in the underlying productivity growth rate casts further doubt on most of the theories that have been used to explain the poor productivity performance of the 1970s. Some argue that slow productivity growth was caused by higher energy prices, the baby boom, inadequate incentives to invest, and inflation and the generally uncertain economic environment. However, all of these factors turned around in the 1980s. Although their reversal might take longer than two or three years to have an effect, at least some signs of improvement in the productivity trend should be appearing; but so far, there are none.

The decline in the rate of return to capital, which also began in the mid-1960s, is as puzzling as the productivity slowdown. Most candidates for explaining the decline are either quantitatively too small or are not timed properly to explain why profits were squeezed in the last half of the 1960s and failed to rebound in the following decade. One possible explanation is that capital's share of output is related to the long-run 
level of labor market tightness. Higher output and low unemployment in the 1960s could have shifted the division of income toward labor, a situation that was maintained throughout the 1970s. Recently, however, the cyclically adjusted net capital share has risen from about 13 percent in early 1981 to about 15 percent in 1983 . We may now be seeing a recovery in the trend of the capital share brought about by back-to-back recessions that produced more severe adjustments than occurred in typical cyclical downturns.

\section{APPENDIX}

\section{Hours, Output, Prices, and Compensation in a Loosely Parameterized System}

I ANALYZED labor productivity and capital's net share of output by using a model (equations 2 through 4) that assumed that both the demand for labor and the price markup over costs could be described by very simple partial-adjustment equations. The relationship between labor hours and real output was assumed to be one of labor demand, with hours chasing a target value determined by an underlying trend in labor productivity and autonomous changes in output, rather than a production function in which output follows labor input. Similarly, the price level was assumed to move toward a target determined by input cost and demand pressure, rather than the other way around, with labor costs being determined by the price level through cost-of-living adjustments or other, less formal mechanisms.

To investigate the possibility that changes in hours and prices may have appeared before the corresponding reactions in output and compensation, measures of association between $H, Y, P$, and $W$ were constructed and then decomposed using a generalization of the standard Granger-Sims tests developed by Geweke. ${ }^{31}$ Table A-1 presents a

31. John Geweke, "Measurement of Linear Dependence and Feedback between Multiple Time Series," Journal of the American Statistical Association, vol. 77 (June 1982), pp. 304-13. 
Table A-1. Measures of Association Relating Changes in Real Output, Labor Hours, Hourly Compensation, and the Price Level ${ }^{\mathrm{a}}$

\begin{tabular}{|c|c|c|c|c|c|}
\hline $\begin{array}{c}\text { Dependent } \\
\text { variable }\end{array}$ & $\begin{array}{c}\text { Independent } \\
\text { variable }\end{array}$ & $\begin{array}{c}\text { Total } \\
\text { association }\end{array}$ & $\begin{array}{c}\text { Feedback } \\
\text { from } \\
\text { independent } \\
\text { to dependent } \\
\text { variable }\end{array}$ & $\begin{array}{l}\text { Contempo- } \\
\text { raneous } \\
\text { association }\end{array}$ & $\begin{array}{c}\text { Feedback } \\
\text { from } \\
\text { dependent to } \\
\text { independent } \\
\text { variable }\end{array}$ \\
\hline Real output & Labor hours & $0.950^{* *}$ & $0.084^{*}$ & $0.822^{* *}$ & 0.044 \\
\hline Labor hours & Real output & $0.944 * *$ & 0.050 & $0.822^{* *}$ & 0.072 \\
\hline Compensation & Price level & $0.354^{* *}$ & 0.044 & $0.228^{* *}$ & $0.080^{*}$ \\
\hline Price level & Compensation & $0.390^{* *}$ & 0.066 & $0.228^{* *}$ & $0.096^{*}$ \\
\hline $\begin{array}{l}\text { Real output and } \\
\text { compensation }\end{array}$ & $\begin{array}{l}\text { Labor hours and } \\
\text { price level }\end{array}$ & $1.912 * *$ & $0.328^{* *}$ & $1.333^{* *}$ & $0.251^{* *}$ \\
\hline $\begin{array}{l}\text { Labor hours and } \\
\text { price level }\end{array}$ & $\begin{array}{r}\text { Real output and } \\
\text { compensation }\end{array}$ & $1.976^{* *}$ & $0.261 * *$ & $1.333 * *$ & $0.382 * *$ \\
\hline
\end{tabular}

* Significant at 5 percent level based on large sample distribution.

** Significant at 1 percent level based on large sample distribution.

a. In each case, the measure of association is $\log \left(\left|S_{t}\right|\left|S_{\jmath}\right|\right)$ where $\left|S_{l}\right|$ is the determinant of the estimated variance/ covariance matrix of residuals in a regression of the form $y_{t}=B(L) y_{t}+C(L) x_{t}+e_{t}$.

decomposition of the associations between $h$ and $y, p$ and $w$, and the pairs $(h, p)$ and $(y, w) .{ }^{32}$ More than 80 percent of the association between hours and output is contemporaneous, which indicates that it is reasonable to estimate how hours will respond to autonomous changes in output, as assumed in the text. The feedback from lagged hours to current output is slightly stronger than the feedback from lagged output to current hours, but it is only marginally significant and not inconsistent with the idea that labor input chases an output target. The association between changes in the deflator and changes in compensation is weaker than the one between hours and output, but again, most of it is contemporaneous. Feedback from lagged compensation to current prices and vice versa is also only on the margin of significance (at the 5 percent level), which is consistent with the observation in the text that prices adjust to compensation within one period.

The multivariate measures of association shown in the last two rows of table A-1 continue to reflect the strong contemporaneous association between hours and output and prices and compensation; they also indicate a substantial amount of cross-equation correlation (the sum of the associations between $(y, w)$ and $(h, p)$ rises almost 50 percent when

32. Lowercase letters denote first differences of logarithms, that is, quarterly rates of change. 
Table A-2. Estimated Disturbance Correlation Matrix for a Vector Autoregression Relating Changes in Real Output, Labor Hours, Hourly Compensation, and Price Level

\begin{tabular}{lcccc}
\hline & $\begin{array}{c}\text { Real } \\
\text { output }\end{array}$ & $\begin{array}{c}\text { Labor } \\
\text { hours }\end{array}$ & $\begin{array}{c}\text { Hourly } \\
\text { compensation }\end{array}$ & $\begin{array}{c}\text { Price } \\
\text { level }\end{array}$ \\
\hline Real output & 1.00 & $\ldots$ & $\ldots$ & $\ldots$ \\
Labor hours & $0.76^{* *}$ & 1.00 & $\ldots$ & $\ldots$ \\
Hourly compensation & $0.30^{* *}$ & $0.22^{*}$ & 1.00 & $\ldots$ \\
Price level & -0.05 & $0.27^{* *}$ & $0.43^{* *}$ & 1.00 \\
\hline
\end{tabular}

* Significantly different from zero at the 5 percent level assuming normality.

** Significantly different from zero at the 1 percent level assuming normality.

price variables are allowed in the hours equation and vice versa). The largest cross-equation feedbacks are from lagged hours to current compensation, which may be related to output mix shifts during business cycle troughs, and from lagged output to current prices, which is the price-cost squeeze effect analyzed in the text.

The apparently complex relationship involving hours, output, prices, and compensation can be examined with a minimum of a priori theory by using a vector autoregression; ${ }^{33}$ that is, each variable can be regressed on its own past values and the past values of all the other variables in the system. This procedure avoids a priori exclusion restrictions and allows any of the variables to be endogenous. The behavior of a vector autoregressive system is best understood by examining the contemporaneous correlations among the error terms in the equations for each variable and the system's impulse response functions, as shown in tables A-2 and A-3.

Table A-2 provides reasonably strong support for the model in the text: the two strongest contemporaneous correlations are between hours and output (0.76) and prices and compensation (0.43), the two relationships represented by partial-adjustment equations in the text. The contemporaneous feedback from output to prices is insignificant, in line with the results in tables 5 and 6 . The contemporaneous correlation between $p$ and $h$ is not accounted for in the text; it suggests that the two

33. The rationale for and estimation of vector autoregressive systems is discussed by Christopher A. Sims in some detail in "Macroeconomics and Reality," Econometrica, vol. 48 (January 1980), pp. 1-48. Note that such a loosely parameterized system implicitly includes both a wage equation and the whole demand side of the economy-pieces of the system excluded in equations 2 through 4 . 
Table A-3. Responses of Labor Hours, Hourly Compensation, and the Price Level to a 1 Percent Impulse in Output

Percent

\begin{tabular}{cccc}
\hline $\begin{array}{c}\text { Quarters } \\
\text { after impulse }\end{array}$ & $\begin{array}{c}\text { Labor } \\
\text { hours }\end{array}$ & $\begin{array}{c}\text { Hourly } \\
\text { compensation }\end{array}$ & $\begin{array}{c}\text { Price } \\
\text { level }\end{array}$ \\
\hline 1 & 0.50 & 0.07 & -0.03 \\
2 & 0.37 & 0.04 & 0.09 \\
3 & 0.18 & 0.06 & 0.04 \\
4 & 0.10 & 0.05 & 0.04 \\
$5-8^{\mathrm{a}}$ & -0.06 & 0.02 & 0.02 \\
$9-16^{\mathrm{a}}$ & -0.01 & 0.02 & 0.03 \\
\hline
\end{tabular}

a. The response values for this period are averages.

partial-adjustment models may be "seemingly unrelated" regressions, ${ }^{34}$ or that some demand-side relationship links the two variables.

The estimated responses of hours, compensation, and prices to an exogenous output shock- "impulse response functions" that include the contemporaneous disturbances indicated in table A-2-are shown in table A-3. The reaction of labor input is almost exactly the same as the one estimated in the text; first-period adjustment of hours is 0.5 (similar to the range of estimates in tables 2 and 3 ), with some overshooting that is eliminated in the second year after the impulse. The compensation response to an output impulse (not considered in the text because there is no wage equation in the system- $y$ and $w$ are both exogenous) is fairly small and spread out over a long period of time. This interaction (rather than any direct effect of output on prices) in turn explains a small, extended price response to an output shock.

The vector autoregression can also be used to test the hypothesis that endogenous changes in policy or behavior make the estimated relationship between $y, h, w$, and $p$ unstable. In particular, the possibility of a shift in behavior after the change in monetary policy in late 1979 can be examined by allowing the parameters in the vector autoregression to change after the third quarter of 1979 and testing whether they are significantly different from the coefficients in the earlier period. A chi-

34. Seemingly unrelated regressions are defined as regressions whose disturbances are contemporaneously correlated; the efficiency of the estimations for such regressions can be improved by exploiting this nonzero covariance. See Arnold Zellner, "An Efficient Method of Estimating Seemingly Unrelated Regressions and Tests for Aggregation Bias," Journal of the American Statistical Association, vol. 57 (June 1962), pp. 348-68. 
square test cannot reject the hypothesis of no change at the 10 percent level. In addition, the absence of equation-by-equation differences cannot be rejected. Evidently, expectations did not change enough to make a significant difference in the relationships estimated by the vector autoregression.

Overall, the "minimum a priori theory" estimates in this appendix do not seem to reveal any major flaws in the hours or price equations presented earlier. Cross-equation associations (uncovered in table A-1) may be the most serious problem, but it is also possible that they are related to demand-side interactions that have been ignored in equations 2 through 4 . A complete restricted model linking the four variables would have to be estimated if one wanted to discover which restrictions (if any) implied by equations 2 through 4 are violated. 


\section{Comments and Discussion}

Robert J. Gordon: Clark's paper contains new findings on three interrelated topics: the behavior of productivity growth, the price-cost markup, and the share of capital. He reaches a major conclusion for each topic, namely that $(a)$ the underlying trend in the growth of labor productivity does not yet show any acceleration from its post-1973 rate of roughly 1 percent toward its historical (post-1890) trend of 2 percent, (b) there is no significant impact of the GNP gap on the price-cost markup and thus no need to make a cyclical correction in evaluating the behavior of the markup, and $(c)$ the net share of capital has recently recovered between one third and one half of its decline from the 1960s to the 1970s. I find Clark's analysis that supports findings $(a)$ and $(c)$ to be persuasive but disagree with finding $(b)$.

A general reservation about the paper is that too much of the analysis and conclusions rests on highly constrained specifications. The same data could be explained in a much less constrained way, and Clark shows that he recognizes this alternative methodology by presenting a set of Granger and vector autoregression test results in an appendix. However, the appendix is not integrated with the tightly specified equations in the main body of the paper and leaves us wondering which of the imposed constraints would be supported by formal statistical tests. I would like to have seen the regressions reported in tables 2, 3, 4, and 6 compared with a relatively unconstrained equation explaining the same dependent variable, together with intermediate versions and formal $F$ tests for the significance of the imposed constraints.

The regressions in the paper address productivity and price markup behavior, while the time path of the net capital share is treated as a residual. Most of my reservations concern the price equations, but let 
me begin with a few comments on the productivity equations. The first thing that one notices about the specification in equation 11 is that no lagged variable appears, except in the term $Y_{t}-H_{t-1}$. Contrast this with the typical equation used in a bivariate Granger test for two variables in quarterly data; such a test would enter a string of four or eight lagged values of both the lagged dependent variable and the explanatory variable, which in this case is output $Y$. If the hypothesis being tested is that the output gap, $Y-Y P$, matters in addition to raw output, then there is no reason to omit lagged values. I can think of as many reasons why the change in the output ratio should matter as much as the level included in equation 11, so that, at a minimum, one extra lag of $Y-Y P$ should have been included. Indeed, when moving from table 2 to table 3 , where static expectations are replaced by an autoregressive scheme for output, the output gap coefficient declines and loses significance. This suggests that a string of lagged terms should have been included in the first place. The "rho" coefficient of serial correlation declines only from 0.66 to 0.45 in moving from table 2 to table 3 , so I suspect that there is residual misspecification that could be removed by additional lags on both the explanatory and dependent variables.

Once one loosens the specification of the hours equation to allow both output and hours to enter with several lags, then one has to confront the troubling evidence of the Geweke/Granger tests hidden away in appendix table A-1. These seem to say that most of the relationship between output and hours is contemporaneous, and that any lagged effect that is present goes more from hours to output than output to hours, as Clark assumes in the lagged adjustment equation explaining hours changes in tables 2 and 3. I don't believe this implication of the appendix table, having convinced myself years ago that hours changes respond both to current and past output changes, but I can't feel comfortable about the unresolved conflict between the appendix and tables 2 and 3 .

Another step beyond the present analysis would divide the post-1979 behavior of nonfarm private productivity into its manufacturing and nonfarm nonmanufacturing components. There has been an explosion of productivity growth in manufacturing since mid-1982 that seems to push manufacturing productivity well above its 1973-79 trend. If the total nonfarm private sector is behaving consistently with its previous trend, as Clark concludes, then the implication is that the nonfarm nonmanufacturing sector has experienced a new and unexplained slow- 
down. A merger of Clark's work on cyclical adjustment with Martin Baily's work on the industry breakdown of the productivity revival would seem a top-priority item on the research agenda. ${ }^{1}$

Turning now to the price equations in the paper, I find the constraints imposed in equation 13 to be more troubling than those in the hours regressions. First, productivity growth is entered only in the form of a trend, with no role for the deviation of actual productivity growth from trend. Only the current level of compensation (relative to trend productivity) is allowed to enter, with no consideration of lags. Third, while dummy variables for the Nixon controls and "oil bulge" are included, there is no exploration of the effect of import prices or the foreign exchange rate except in the non-oil sector regressions of table 7.

The omission of the deviation of productivity growth from trend prevents Clark from providing a clear interpretation of the interrelations among productivity, markup, and capital's share. Using lowercase letters to represent percentage rates of growth, we can write an identity that relates the rate of change of the price level to the rate of change of unit labor cost, $w-x$, and unit labor income, $z-y$, where $w, x, z$, and $y$ are the growth rates of the nominal wage, productivity, nonlabor income, and output, respectively:

$$
p=a(w-x)+(1-a)(z-y) .
$$

Here nonlabor cost includes not just Clark's net capital income but also indirect business taxes and depreciation. Equation 1 can be rearranged to set inflation equal to growth in actual unit labor cost plus a fraction of any change in unit real nonlabor income:

$$
p=w-x+\frac{(1-a)}{a}(z-y) .
$$

Now let us pretend that there is a "structural" markup equation that relates price change to the change in standard unit labor cost, $w^{*}-x^{*}$, plus a coefficient times some demand variable $d$, minus a fraction of the deviation between actual and trend productivity growth, plus a coefficient times the difference between actual wage growth, $w$, and the wage growth concept, $w^{*}$, used by firms in calculating standard unit labor cost:

1. Martin Neil Baily, "The Productivity Growth Slowdown by Industry," BPEA, 2:1982, pp. 423-54. 


$$
p=w^{*}-x^{*}+c d-b\left(x-x^{*}\right)+e\left(w-w^{*}\right) .
$$

When equation 3 is substituted into 2 , we obtain the expression for the change in real unit nonlabor cost, which is real net capital income per unit of output, if indirect business taxes and depreciation per unit of output are assumed to be constant:

$$
z-p-y=\frac{a}{1-a}\left[(1-b)\left(x-x^{*}\right)+(1-e)\left(w-w^{*}\right)+c d\right] .
$$

Here we find a crucial result in the relationship between productivity, price, and profits that is not discussed in the paper: the cyclical response of profits to deviations of productivity growth from trend depends on $b$ and does not occur at all if $b$ is unity. The closer $b$ approaches zero, the more cyclical productivity fluctuations pass through to profits, and the less they affect prices. Similarly, the deviation between actual and smoothed wage change also affects the time path of profits, with an impact if $e$ is less than unity.

Clark's price equations in table 6 do not include either deviation term. The unit labor cost concept is current wage cost, $w$, relative to trend productivity, $x^{*}$. The omission of the productivity term, which enters equation 3 with a minus sign, should bias the coefficient on the output gap toward zero if the productivity deviation is positively correlated with the output gap, as must surely be the case (here I treat the output gap as the log ratio of actual to potential output). The omission of $w^{*}$, some sort of smoothed or moving average wage concept, also is likely to bias toward zero the coefficient on the output gap if $w-w^{*}$ is positively correlated with output.

To limit the length of the comment, I do not report a full set of estimated price markup equations. However, I have done enough experimentation to convince myself that Clark's low and insignificant output gap coefficients are an artifact of his particular specification. A model I refer to as A regresses the rate of change of Clark's price variable on a constant; a Nixon control dummy; a smoothed unit labor cost series, $w^{*}-x^{*}$, that uses Clark's compensation data; a variable to capture the effect of changes in the relative prices of food and energy; and, last, the current value and eight lags of the output gap. ${ }^{2}$ An alternative, model B,

2. See Robert J. Gordon, "Inflation, Flexible Exchange Rates, and the Natural Rate of Unemployment," in Martin Neil Baily, ed., Workers, Jobs, and Inflation (Brookings Institution, 1982), pp. 89-152. The food-energy variable is the difference between the 
replaces the smoothed labor cost series with the current value and eight lags of the difference between the growth rates of compensation and trend productivity. Both models A and B were also estimated using as a dependent variable the change in the fixed-weight GNP deflator. The coefficients and $t$-statistics on the output gap are as follows.

$\begin{array}{ll}\text { Model A, Clark price series } & 0.137(2.01) \\ \text { Model B, Clark price series } & 0.061(0.90) \\ \text { Model A, fixed-weight deflator } & 0.123(2.69) \\ \text { Model B, fixed-weight deflator } & 0.087(1.76)\end{array}$

It would take much more research to determine why Clark finds such weak output gap effects, and how these effects interact with omitted variables. Perhaps the various trend terms included in Clark's equation soak up the output gap effect that I find. It would be preferable to pursue this research agenda by running equations not only for the price-cost markup, but at the same time (with compatible data and sample periods) for wage costs and for a reduced-form equation relating inflation to past inflation (without any reference to costs). My previous research ${ }^{3}$ indicates strong output gap effects in the reduced-form approach, and I suspect that price-cost markup equations lose some of the cyclical impact of the output gap on the inflation process, owing to simultaneity between wage costs and prices.

Charles L. Schultze: Peter Clark's paper convincingly argues that the behavior of aggregate labor input in the recession and recovery to date offers no evidence of any significant upward shift in the disappointingly low trend growth of productivity. My comments on this part of his paper are mainly in the nature of refinements. I do have more serious questions about the second part of the paper: his treatment of price-wage margins suffers from aggregation and index-number problems. And in view of the shift within the capital stock to shorter-lived assets, I wish he had provided some discussion of whether the benchmark for profit performance ought to be stability in the gross or in the net capital share. Last,

growth rates of the fixed-weight personal consumption deflator gross and net of expenditures on food and energy. The output gap is the log output ratio, from appendix B in Gordon ('Inflation"). The Nixon dummy is the same as Clark's. The smoothed labor cost series is the variable Clark used in his first draft, that is, $c^{*}=0.2 c+0.8 c^{*}$.

3. Gordon, "Inflation." 
I have some questions about his speculation that labor scarcity explains the continued weakness in the cyclically adjusted net profit share.

Let me start with the productivity section of the paper and make a few comments about the structure of Clark's adjustment model. It is drawn from a black box in which the sum of two unspecified kinds of costs, each obeying a quadratic function, is minimized. The first kind is the adjustment costs of hiring or firing workers. That cost must be balanced against the second kind, the cost of operating with an excessive or insufficient number of workers. Trying to think about some of the specifics of the mechanism inside the black box suggested a few hypotheses about the adjustment process that can be seen as refinements to, and cautions about, the interpretation of Clark's cyclical adjustment model.

The major cost of adjustment arises because of the possibility of guessing wrong about future output. To a varying extent with different classes of workers, firms have to make an investment in human capital. Unless the same worker can be rehired, firing skilled workers subjects the firm to the risk that labor requirements will be higher than were anticipated, and the firm will have to make additional training investments. Conversely, hiring workers whose services subsequently turn out to be unneeded also wastes human capital investment. This type of adjustment cost equals the expected value of the excess investment in human capital associated with actual output being different from target output. It is in effect indexed by the risk of having to reverse a hiring or firing decision. But if the distribution of expected outcomes around the target level of output is independent of the size of the most recent output change, then large output changes can be accompanied by a larger adjustment of employment without proportionately increasing the risk of reversal. In the underlying function these costs are not quadratic. Clark's adjustment factor $a_{1}$ may well increase for large output changes.

The other side of the coin is the cost of retaining excess workers during a period of output decline or operating with a suboptimal work force in a period of expansion. Since small numbers of supernumerary workers can be profitably put to work for a short time in plant maintenance and other jobs, the cost of retraining excess workers should be negligible for small output declines. But beyond some point the costs should begin to rise: here the response is nonlinear and increasing.

On both of these counts it is reasonable to suppose that the adjustment 
coefficient $a_{1}$ may be higher for large changes in output than for small. I tested this in a rudimentary fashion. I first fitted equations very similar to the ones reported by Clark in tables 2 and 3 . This first iteration gave a value for target hours. I then constructed a variable which was equal to the absolute value of the change in output whenever the change in output (relative to potential output) was larger than one standard deviation: call this term large $\triangle G A P$. The nonlinear adjustment coefficient $a_{1}+$ $\mathrm{a}_{11}($ large $\triangle G A P)$ was estimated. The $a_{11}$ component of the coefficient was significant at the 5 percent level. What it showed was an adjustment coefficient for small changes in the GAP that was less than Clark's adjustment coefficient but rose toward 0.5 when very large output changes occurred. This modification implies a slightly different cyclical pattern of productivity growth but should not yield any results that change Clark's basic conclusions about the absence of a substantial recent improvement in productivity.

If cost minimization dictates carrying excess workers in periods of recession, then output itself may be endogenous to employment decisions. If excess workers are to be carried, why let them sit around doing nothing? Since the marginal cost of extra output is small, it may pay to produce more for inventory. Or, since "true" marginal costs are low, prices may be cut and extra sales and output generated. I have no idea how quantitatively important this might be, but to the extent it is significant it will tend to bias Clark's $a_{1}$ adjustment coefficient up. And since the potential output consequences of carrying excess workers during recession are asymmetrical with the consequences of carrying insufficient workers during booms, some distinction in the coefficient between upward and downward movements may be needed.

Turning to the rest of the paper, I will comment on two aspects of Clark's treatment of the net capital share. First, in his equation that explains the margin of prices over standard unit labor costs he uses a price deflator and a "raw" measure of compensation per hour (total payrolls divided by aggregate hours worked). But this choice of measures generates what I believe may be substantial aggregation problems. The price deflator is a Paasche index; as a consequence the index change from one period to the next will tend to be biased down relative to a Laspeyres fixed-weight price index during years after the 1972 base period (and biased up in years before the base period) by the tendency 
for the composition of output to shift toward products whose relative prices have fallen. ${ }^{1}$ There is no reason to believe that there is any systematic cyclical behavior to such output shifts. (A regression of the ratio of the private nonfarm deflator and a fixed-weight index for the same sector does not yield a significant coefficient on current or lagged values of the output gap.) Changes in the raw compensation index, however, are systematically affected by any shift in employment toward industries that have absolutely higher wages (regardless of how wages have changed since the base period). And we know that there is a systematic tendency for output to shift toward high-wage industries in expansion and vice versa in recession. Hence a raw compensation index, because of changing product mix, will systematically vary around a fixed-weight wage index in a procyclical manner.

The first column of the table below shows the regression coefficients on lagged values of the output gap in an equation whose dependent variable is the ratio of the raw BLS index of private nonfarm compensation per hour to an index of nonfarm wages and salaries that is adjusted to exclude both overtime in manufacturing and the effects of interindustry shifts. ${ }^{2}$ The raw compensation index systematically increases relative to the fixed-weight index as the lagged output gap increases. (A regression of manufacturing hourly earnings including overtime on an index excluding overtime suggests that overtime is not the principal reason for this behavior.) Thus, there is a tendency for Clark's compensation index to behave procyclically_albeit with a rather long lag-for reasons of product-mix change. The procyclical shift in employment toward higher-

1. The base year for the deflators in the national income accounts is 1972 . In years before 1972 the Paasche index increases more than a fixed-weight index since the "given" year in the Paasche index is the earlier year. From 1972 on, the deflator will tend to increase less than a fixed-weight index, because in years after 1972 the given year will be the later year. From 1959 to 1972 the ratio of the deflator to the fixed-weight private nonfarm index rises by 3.2 percent and from 1972 to 1980 it falls by 3.7 percent. The entire move represents a monotonic mix shift toward goods whose relative supply price has fallen. The total divergence of levels for the 21-year period is substantial-approximately 7 percent.

2. This index is a modification of the fixed-weight index introduced by Robert $\mathbf{J}$. Gordon, "Inflation in Recession and Recovery," BPEA, 1:1971, pp. 115-16; the index of hourly earnings, adjusted for overtime in manufacturing and interindustry shifts, is blown up each year to reflect the national income account ratio of compensation to wages and salaries. In addition, since the fixed-weight index excludes pay of salaried workers, which the compensation index does not, I adjusted the former so that its trend over the postwar period equaled the trend of the latter. 
wage industries is presumably also a shift toward industries with higher productivity. The procyclical movements in the raw compensation index, generated by changes in employment mix, are matched by similar movements in productivity - the one cancels out the other, and there is no net effect on standard unit labor costs for the economy as a whole. But Clark's standard unit labor cost index excludes all cyclical productivity effects, so that the cyclical effects of product-mix change on his compensation index are not canceled out by upward shifts in productivity. As a consequence he gets a spurious procyclical component in his standard unit labor costs. In turn this spurious component of unit labor cost variations may be canceling a systematic procyclical change in

Regressions with Alternative Wage and Price Indexes ${ }^{a}$

\begin{tabular}{|c|c|c|c|}
\hline \multirow[b]{3}{*}{ Coefficient } & \multicolumn{3}{|c|}{ Dependent variable } \\
\hline & \multirow[b]{2}{*}{$\begin{array}{c}\text { Ratio of } \\
\text { wage indexes }\end{array}$} & \multicolumn{2}{|c|}{ Margin $^{\mathrm{b}}$} \\
\hline & & $\begin{array}{l}\text { Deflator and } \\
\text { compensation- } \\
\text { per-hour index }\end{array}$ & $\begin{array}{l}\text { Fixed-weight } \\
\text { wage and } \\
\text { price indexes }\end{array}$ \\
\hline Time trend, pre- 1965 & $\begin{array}{l}0.24 \\
(1.9)\end{array}$ & $\begin{array}{l}0.05 \\
(0.3)\end{array}$ & $\begin{array}{l}-0.12 \\
(-1.1)\end{array}$ \\
\hline Change in trend, 1965 & $\begin{array}{l}-0.39 \\
(-2.1)\end{array}$ & $\begin{array}{l}-0.78 \\
(-3.0)\end{array}$ & $\begin{array}{l}-1.25 \\
(-6.5)\end{array}$ \\
\hline Change in trend, 1971 & $\begin{array}{r}0.09 \\
(0.6)\end{array}$ & $\begin{array}{l}0.41 \\
(1.7)\end{array}$ & $\begin{array}{r}1.45 \\
(8.0)\end{array}$ \\
\hline Output $G A P(-1)$ & $\begin{array}{l}0.08 \\
(1.6)\end{array}$ & $\begin{array}{l}0.09 \\
(1.4)\end{array}$ & $\begin{array}{r}0.23 \\
(4.9)\end{array}$ \\
\hline Output $G A P(-2)$ & $\begin{array}{l}0.14 \\
(2.1)\end{array}$ & $\begin{array}{r}0.05 \\
(0.7)\end{array}$ & $\begin{array}{r}0.24 \\
(4.0)\end{array}$ \\
\hline Output $G A P(-3)$ & $\ldots$ & $\begin{array}{l}0.07 \\
(0.9)\end{array}$ & $\begin{array}{l}0.14 \\
(2.4)\end{array}$ \\
\hline Summary statistic & & & \\
\hline $\bar{R}^{2}$ & 0.75 & 0.97 & 0.98 \\
\hline Standard error & 0.46 & 0.51 & 0.38 \\
\hline Durbin-Watson & 1.41 & 1.78 & 2.07 \\
\hline
\end{tabular}

a. All equations fit to 1960-80 with annual data; the years of price control and price control "snapback" (197275) were excluded. Equations were fit in logs of variables but results were scaled in the table to relate to percentage ratios and changes. Constant not shown. Numbers in parentheses are $t$-statistics.

b. Partial adjustment coefficient constrained to 1.0. Clark-type productivity equations were used to derive the standard unit labor costs; Clark's dating of time trends was used; and my own estimate of the direct effect of domestic energy price increases was subtracted from price indexes for 1974-80. No autoregression correction was applied. 
margins. That may be one of the reasons why Gordon, who uses a fixedweight wage index, finds a systematic effect of the output gap on margins while Clark does not.

The second and third columns of my table present the output gap coefficients obtained by fitting margin equations similar to Clark's (the price control years, 1972-75, were excluded rather than handled with questionable annual dummies). The second column is an imitation of Clark's equation and is based on the private nonfarm deflator and the raw compensation index. The third column is based on fixed-weight wage and price indexes. When the margin changes are defined as changes in the deflator relative to the raw compensation index in the second column, then just as Clark finds, there is no significant cyclical component. But when the fixed-weight indexes are used, a long-lagged cyclical effect is evident.

My main point is not to assert with any confidence that margins definitely behave in a procyclical manner-the length of the lags on the output gap is hard to rationalize as a purely demand-induced phenomenon. But this demonstration at least suggests that there are severe aggregation problems when one tries to infer the contribution of margin changes to changes in capital's share of income on the basis of price, wage, and productivity indexes whose weighting schemes are not the theoretically appropriate ones.

Ignoring changes in indirect taxes, capital's share could change either because (1) the constantly weighted average of individual industry margins had changed, or (2) output had shifted to industries with higher (or lower) capital intensity, or (3) output had shifted toward industries whose return on capital was in disequilibrium and temporarily higher (or lower) than average. To test whether the first factor has contributed to margin changes, it would be necessary to take a price index weighted with base or given-year weights and compare it with a unit labor cost index weighted correspondingly with base or given-year weights. Clark's margin index is related to the appropriate index as follows.

$$
\text { Clark's margin }=\frac{P_{t}^{g}}{U L C_{t}^{h}}=\frac{P_{t}^{g}}{U L C_{t}^{g}} \frac{\bar{L}_{0}}{\sum_{i}\left(L_{0} A_{t}\right)_{i}},
$$


where

$P_{t}^{g}=$ deflator in year $t$

$U L C_{t}^{h}=$ raw unit labor cost index derived by dividing the aggregate payroll by aggregate hours

$U L C_{f}^{g}=$ given-year weighted standard unit labor cost index

$=$ the current unit labor cost of producing current output divided by base period unit labor cost of producing current output $^{3}$

$\bar{L}_{0}=$ economy-wide base period labor share

$\left(L_{0} A_{t}\right)_{i}=$ base period unit labor share in industry $i$ multiplied by current output share of industry $i$.

Shifts in output toward industries with a lower base period labor share (higher base period capital share) will show up in Clark's margin index as a change in capital share due to margin changes, whereas it was in fact due to an output shift. Moreover, even if it were possible to isolate a "true" margin change from the effects of an output shift, we would have to sort out shifts to more capital-intensive industries from shifts to industries whose returns are high for disequilibrium reasons in order to draw any conclusions about the equilibrium or disequilibrium nature of the change in shares. The fact that from 1959 to 1980 the private nonfarm deflator cumulatively changed by 7 percent relative to a fixed-weight deflator because of mix shifts should warn us that such shifts could conceivably be an important element in explaining changes in the share of capital. Most of the relative shift of aggregate supply curves among individual industries, which led to the changing relationship of the deflator to the fixed-weight index, may well have been due to relative changes in unit labor costs. But to assume that fact begs the question.

Let me turn to Clark's conclusions with respect to a falling capital share. He concentrates on cyclically adjusted net income to capital as a share of GNP. But since the mid-1960s the share of economic depreciation in GNP has risen steadily as the stock of equipment has grown relative to the stock of plant. As Bosworth has pointed out, ${ }^{4}$ the flow of capital services has risen relative to the capital stock. If the production

3. A "true" unit labor cost index cannot be constructed by dividing a base (given) year wage index by a base (given) year productivity index.

4. Barry P. Bosworth, "Capital Formation and Economic Policy," BPEA, 2:1982, pp. 273-317. 
function is Cobb-Douglas in terms of the relationship between gross output and the flow of capital services, then should we not expect constancy in the gross share of capital income? Further, gross product at factor costs (that is, excluding indirect taxes) should be used as the denominator in measuring the functional income shares. On this basis, the cyclically adjusted gross return to capital as a percent of gross factor income in 1980-83 had almost recovered to the level of the second half of the 1960s, although not to the peak ratios of the 1955-64 period. The magnitude of the remaining "squeeze" to be explained may not be so large after all.

Clark speculates that the squeeze on profits that started in the late 1960 s and lasted through the 1970s might have resulted from the relative scarcity of labor resources: "Generally tight labor market conditions in the late 1960s and early 1970 s could have shifted the balance of power in favor of labor, cutting into capital's share." From the standpoint of real wages and functional income shares, the only relevant meaning to the term "scarcity of labor resources" is its scarcity relative to other factors, principally capital. An increasing "scarcity" of labor, therefore, implies a rise in the marginal (and average) product of labor and a larger than trend rise in the capital-labor ratio. These conditions might indeed have characterized the investment boom of the 1960s and explained the rise in labor's share during those years. But they are not typical of the 1970s. The growth of the labor force was enormous and above trend; the growth in the capital-labor ratio was subnormal; and the growth rate of average labor productivity fell (implying a decline in marginal productivity growth). The stylized facts of the last seven or eight years of the 1970s just do not fit Clark's explanation, and it is hard to believe that adjustment lags are so long as to cause shares during the 1970 s to move as if the investment boom of the 1960 s were still in operation.

\section{General Discussion}

Much of the discussion centered on evidence about the productivity trend. Martin Baily reported that productivity data from manufacturing suggested the trend was improving, even though there was little sign of it in data that Clark had analyzed for the nonfarm business sector as a whole. He pointed out that data on both sectors posed measurement problems; uncertainty about the flow of inputs into manufacturing made 
it hard to estimate manufacturing output, while uncertainty about output price indexes elsewhere in the economy made it difficult to estimate nonfarm business output as a whole. He concluded that one ought to pay attention to available data from both sectors. Not only did the manufacturing data suggest some recovery had occurred in the productivity trend, but the improvement in energy prices, demographics, and inflation-potential sources of productivity weakness in the past-also pointed in that direction. Baily further observed that there was great uncertainty about how to cyclically adjust productivity or how to make cyclical comparisons of this recession and expansion with previous ones. For all these reasons, he regarded it as premature to make judgments about the current productivity trend.

Benjamin Friedman reasoned that, regardless of whether one expected an improved productivity trend, it was simply too early to judge the trend coming out of the recent recession. Moreover, it was also too early for the improved fundamentals to have had any effect. Tax changes to enhance capital spending and research and development by business and the stabilization of oil prices were both developments that might ultimately be favorable for productivity. But nobody should have expected any measurable effect this soon. George Perry agreed that the benefits of capital formation were modest at best and, in any case, would not yet exist, because capital formation had been depressed by the recession and high interest rates. However, he did find it surprising that the economy-wide data analyzed by Clark revealed no improvement in productivity that might have come from changing work rules and improving management efficiencies; the deep recession and foreign competition had presumably spurred attempts to improve productivity and reduce costs in these ways, and such effects would have shown up by now if they were significant. He also believed that if higher fuel costs had been an important part of the productivity slowdown, enough time had passed for their depressing effects to have vanished, since oil prices had been stable or declining since 1980 .

Charles Holt suggested that the difficult problem of adjusting productivity for the business cycle might be addressed more directly than Clark had done. Clark based his adjustment on the operations research literature in which a business understands its cost structure and derives optimal decision rules for employment based on it. In place of Clark's use of observed total hours to infer the firm's target employment and its 
adjustment toward that target, Holt suggested using overtime hours and regular hours separately. Regular hours include a variable amount of slack, while overtime hours more nearly reflect periods when labor is being fully utilized, with little slack and maximum productivity. At such times, the regular hours are also being used effectively. Thus the amount of overtime becomes a useful proxy for the amount of slack in total hours worked. Holt reasoned that, since slack actually accounts for much of the strong cycle in productivity, that cycle could be better isolated and taken into account by explicitly using overtime hours.

Edward Denison reinforced Clark's main conclusion that there is no evidence of an improved productivity trend as yet. In contrast to Baily, Denison argued that aggregate data were far more reliable than the data for manufacturing, and reported that detailed estimates of potential national income per potential hour worked in the nonresidential business sector slowed from a 3.1 percent annual growth rate between 1948 and 1973 to only a 0.6 percent growth rate from 1973 to 1982 . Such an enormous difference could not be eliminated by any alternative adjustment procedure for inferring potential from actual data. Furthermore, when he broke the latter period in two, he found a 0.9 percent growth rate in productivity from 1973 to 1979 and no productivity growth at all between 1979 and 1982. Although the 1979-82 estimate is subject to error because of the short data period, Denison reasoned that even a cyclical adjustment substantially different from his own would not reverse the verdict that the productivity trend was still very slow by historical standards.

Edmund Phelps observed that the major decline in the capital share that Clark had measured might be explained by the model he had developed earlier with Sidney Winter in which a substantial part of a firm's profits represents a return to goodwill rather than to capital. As real interest rates decline, firms become more price competitive as they "invest" more intensively for customers' goodwill in order to improve profits over a longer horizon. High real interest rates, by contrast, cause firms to discount the future relative to the present and lead them to try to increase present profits rather than present goodwill. Phelps suggested this behavior might explain the large decline in the capital share between the 1960s and 1970s and would also predict a rise in the capital share now that the real interest rate has risen so much. 